\title{
The annual ammonia budget of fertilised cut grassland - Part 2: Seasonal variations and compensation point modeling
}

\author{
C. R. Flechard ${ }^{1}$, C. Spirig ${ }^{2}$, A. Neftel $^{2}$, and C. Ammann ${ }^{2}$ \\ ${ }^{1}$ INRA, Soils, Agro- and hydro-Systems (SAS) Unit, 65, rue de St.-Brieuc, 35042 Rennes Cedex, France \\ ${ }^{2}$ Agroscope Reckenholz-Tänikon ART, Swiss Federal Research Station, Reckenholzstrasse 191, 8046 Zürich, Switzerland
}

Received: 3 September 2009 - Published in Biogeosciences Discuss.: 7 October 2009

Revised: 6 January 2010 - Accepted: 15 January 2010 - Published: 8 February 2010

\begin{abstract}
The net annual $\mathrm{NH}_{3}$ exchange budget of a fertilised, cut grassland in Central Switzerland is presented. The observation-based budget was computed from semicontinuous micrometeorological fluxes over a time period of 16 months and using a process-based gap-filling procedure. The data for emission peak events following the application of cattle slurry and for background exchange were analysed separately to distinguish short-term perturbations from longer-term ecosystem functioning. A canopy compensation point model of background exchange is parameterised on the basis of measured data and applied for the purposes of gap-filling. The data show that, outside fertilisation events, grassland behaves as a net sink for atmospheric $\mathrm{NH}_{3}$ with an annual dry deposition flux of $-3.0 \mathrm{~kg} \mathrm{~N} \mathrm{ha}^{-1} \mathrm{yr}^{-1}$, although small $\mathrm{NH}_{3}$ emissions by the canopy were measured in dry daytime conditions. The median $\Gamma_{s}$ ratio in the apoplast $\left(=\left[\mathrm{NH}_{4}^{+}\right] /\left[\mathrm{H}^{+}\right]\right)$estimated from micrometeorological measurements was 620 , equivalent to a stomatal compensation point of $1.3 \mu \mathrm{g} \mathrm{NH}_{3} \mathrm{~m}^{-3}$ at $15^{\circ} \mathrm{C}$. Non-stomatal resistance to deposition $R_{w}$ was shown to increase with temperature and decrease with surface relative humidity, and $R_{w}$ values were among the highest published for European grasslands, consistent with a relatively high ratio of $\mathrm{NH}_{3}$ to acid gases in the boundary layer at this site. Since the gross annual $\mathrm{NH}_{3}$ emission by slurry spreading was of the order of $+20 \mathrm{~kg} \mathrm{Nha}^{-1} \mathrm{yr}^{-1}$, the fertilised grassland was a net $\mathrm{NH}_{3}$ source of $+17 \mathrm{~kg} \mathrm{Nha}^{-1} \mathrm{yr}^{-1}$. A comparison with the few other measurement-based budget values from the literature reveals considerable variability, demonstrating both the influence of soil, climate, management and grassland type on the $\mathrm{NH}_{3}$ budget and the difficulty of scaling up to the national level.
\end{abstract}

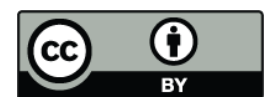

Correspondence to: C. R. Flechard (chris.flechard@ rennes.inra.fr)

\section{Introduction}

The relative importance of ammonia $\left(\mathrm{NH}_{3}\right)$ as an atmospheric pollutant has increased in Europe over the last two decades. The implementation within the UNECE Convention on Long-Range Transboundary Air Pollution of the Helsinki and Oslo Protocols on sulphur (1985, 1994), of the Sofia Protocol on nitrogen oxides (1988), and of the Gothenburg Protocol to abate acidification, eutrophication and ground-level ozone (1999), will likely eventually result in $\mathrm{NH}_{3}$ being the main contributor to acidifying deposition (Amann et al., 2005). Other environmental impacts of $\mathrm{NH}_{3}$ deposition include ecosystem eutrophication, loss of biodiversity as well as direct effects of gaseous $\mathrm{NH}_{3}$ on plants, nitrification and leaching of nitrate $\left(\mathrm{NO}_{3}^{-}\right)$to groundwater, ammonium $\left(\mathrm{NH}_{4}^{+}\right)$aerosol formation, and contribution to climate change through deposition-induced $\mathrm{N}_{2} \mathrm{O}$ emission (Galloway et al., 2003; Erisman et al., 2007).

Grasslands are widely recognised as both sources and sinks of $\mathrm{NH}_{3}$, depending on their fertilisation status, but also on the time of day and season of year. Semi-natural and unfertilised agricultural grasslands have been observed to behave mostly as sinks during night-time and winter, with occasional emissions occurring at noon and in the summer (Hesterberg et al., 1996; Flechard and Fowler, 1998; Milford et al., 2001a; Spindler et al., 2001; Horvath et al., 2005; Wichink Kruit et al., 2007). Intensively managed grasslands, however, are generally net $\mathrm{NH}_{3}$ emitters (Plantaz, 1998; Mosquera et al., 2001; Milford, 2004), with $\mathrm{NH}_{3}$ emissions being triggered or enhanced by management practices such as mineral fertilisation (Bussink et al., 1996; Herrmann et al., 2001, 2009; Milford, 2004; Mattsson et al., 2009) and manure application (Mosquera et al., 2001); by grazing animals (Plantaz, 1998; Milford, 2004) or even large numbers of birds (Mosquera et al., 2001); by the cutting of grass and the decomposition of left-over or senescent plant

Published by Copernicus Publications on behalf of the European Geosciences Union. 
material in a leaf litter (Burkhardt et al., 2009; Milford, 2004; Mannheim et al., 1997); and generally, by an elevated plant nitrogen $(\mathrm{N})$ status resulting in a compensation point being higher than the ambient concentration, leading to $\mathrm{NH}_{3}$ loss through stomata (Mattsson et al., 2009; Massad et al., 2008; Sutton et al., 1998; Farquhar et al., 1980).

Over grazed or fertilised agro-ecosystems, the continuous or discontinuous supply of animal excreta, urine, manure or slurry, or synthetic nitrogen $(\mathrm{N})$-containing fertilisers, leads to both direct, short-term $\mathrm{NH}_{3}$ emissions following the application, and indirect and longer-term plant- or soil-mediated exchange by raising the $\mathrm{N}$-status of the system (Riedo et al., 2002; Herrmann et al., 2001). In the case of fertiliser application to non-grazed systems, emission bursts or "events" may be considered as short-lived disturbances of the system, which gradually reverts to a state of equilibrium or "background" exchange with the atmosphere. Unlike background exchange, which exhibits rather regular diurnal and seasonal patterns controlled by meteorology and grassland growth and phenology, peak emissions from fertiliser application are characterized by strong asymmetrical dynamics over a few days with successive pulses of decreasing strength. The emission flux and $\mathrm{NH}_{3}$ surface concentration thus decrease rapidly, broadly following an exponential decay curve (Spirig et al., 2010; Génermont et al., 1998; Thompson and Meisinger, 2004) back to values close to those observed prior to fertilisation.

Most micrometeorological measurements to date of the surface/atmosphere exchange of $\mathrm{NH}_{3}$ over intensively managed grassland have been carried out within the framework of relatively short campaigns of typically a few weeks (e.g. the GRAMINAE Braunschweig campaign, Sutton et al., 2008, 2009). In contrast, long-term monitoring studies that encompass the full range of management activities (grazing, cutting, fertiliser applications) as well as the whole annual vegetative cycle, are scarce and largely limited to the oceanic climatic zone of NW Europe (Plantaz, 1998; Mosquera et al., 2001; Milford, 2004). The results indicate that the gross emission from all processes in fertilised grassland, including emissions from fertilisation, grazing and cutting, can make a significant contribution to national $\mathrm{NH}_{3}$ emissions (Milford, 2004). The annual $\mathrm{NH}_{3}$ budgets reported at the intensively managed grassland site of Schagerbrug and at the semi-natural site of Oostvaardersplassen in Northern Netherlands (Mosquera et al., 2001), at Zegveld in Central Netherlands (Plantaz, 1998), and at Easter Bush in Southern Scotland (Milford, 2004), all show management event-dominated emission budgets that are somewhat offset by dry deposition during a large part of the year. Only one of these sites (Schagerbrug) was ungrazed, and very few measurementbased estimates of the annual $\mathrm{NH}_{3}$ budget for fertilised, cut grasslands are available in the literature.

In this paper we report a year-long, semi-continuous time series of field measurements of $\mathrm{NH}_{3}$ exchange over fertilised cut grassland in a continental climate (Switzerland).
To describe the exchange mechanistically and fill gaps in the flux time series, the single-layer canopy compensation point modeling framework of Sutton et al. (1998) is parameterised and applied in background conditions. The extent to which a grassland canopy may be satisfactorily approximated by a single-layer model for the purpose of simulating background $\mathrm{NH}_{3}$ exchange is discussed. The data are used to derive parameterisations for single-layer exchange frameworks that are widely applied in regional atmospheric transport and deposition models (Sorteberg and Hov, 1996; Smith et al., 2000; Simpson et al., 2003).

The case of strong $\mathrm{NH}_{3}$ emissions after cattle slurry application is treated separately, as processes leading to $\mathrm{NH}_{3}$ evolution from liquid manure applied onto soils are different altogether from those regulating background exchange (e.g. Génermont and Cellier, 1997). The full description of flux measurements during slurry "events" and the uncertainty introduced by advection and footprint errors (Loubet et al., 2001; Neftel et al., 2008) are treated in the companion paper by Spirig et al. (2010).

The main objectives of this paper were therefore 1) to study seasonal variations in $\mathrm{NH}_{3}$ exchange over fertilised cut grassland; 2) to identify key parameters driving background ammonia exchange; 3 ) to parameterise a canopy compensation point model (Sutton et al., 1998) for this grassland site; and 4) to calculate an annual, observation-based $\mathrm{NH}_{3}$ budget based on both background and peak emission fluxes.

\section{Materials and methods}

\subsection{Site description}

Turbulent $\mathrm{NH}_{3}$ fluxes were measured over grassland at the Oensingen CarboEurope-IP (http://www.carboeurope. org) and NitroEurope-IP (http://www.nitroeurope.eu) experimental site in central Switzerland (longitude $7^{\circ} 44^{\prime}$ E, latitude $47^{\circ} 17^{\prime} \mathrm{N}$, elevation $450 \mathrm{~m}$ a.m.s.l., mean annual temperature $9.5^{\circ} \mathrm{C}$, mean annual rainfall $1200 \mathrm{~mm}$ ). The grassland site has been described in detail in Ammann et al. (2007) and in the companion paper by Spirig et al. (2010), and comprises an unfertilised, extensively managed plot (hereafter referred to as "EXT") as well as an intensively-managed ("INT") field, the latter receiving normally about $200 \mathrm{~kg} \mathrm{~N} \mathrm{ha}^{-1} \mathrm{yr}^{-1}$ in the form of cattle slurry and ammonium nitrate applications. However, at the time the measurements started in June 2006, no slurry had been applied to the field since 5 July 2005. Annual total (wet+dry) atmospheric $\mathrm{N}$ deposition at the site has previously been estimated to be of the order of $23 \mathrm{~kg} \mathrm{Nha}^{-1} \mathrm{yr}^{-1}$ (Ammann et al., 2009). Both grassland plots were cut several times per year, the grass being used as hay or silage, and there was no grazing. Soil $\mathrm{pH}, \mathrm{C} / \mathrm{N}$ ratio and CEC were measured in 2001, with values of 7.5, 9.2 and 21 to $27 \mathrm{meq} / 100 \mathrm{~g}$ dry soil, respectively, and no significant difference between INT and EXT at that time. 


\subsection{Micrometeorological measurements}

Semi-continuous micrometeorological $\mathrm{NH}_{3}$ flux measurements took place from July 2006 through October 2007, with interruptions in winter (December to February) and in late summer 2007. Turbulent fluxes were determined for every half-hour period using the aerodynamic gradient method or AGM (Monteith and Unsworth, 1990) from the product of friction velocity $u_{*}$, measured by an ultrasonic anemometer according to CarboEurope-IP guidelines (Ammann et al., 2007), and of the stability-corrected, vertical gradient in $\mathrm{NH}_{3}$ concentration $(\chi)$ :

$$
F_{\chi}=-k u_{*} \frac{\partial \chi}{\partial\left(\ln (z-d)-\psi_{H}\left(\frac{z-d}{L}\right)\right)}
$$

where $z$ is height above ground, $d$ is the displacement height, $k$ is von Karman's constant (0.41), $L$ is Monin-Obukhov length and $\psi_{H}$ is the integrated stability function for heat and trace gases (for details see Spirig et al., 2010). Ammonia concentrations were measured at two heights above the canopy using AiRRmonia detectors (Mechatronics, Hoorn, The Netherlands; http://www.mechatronics.nl; see also Erisman et al., 2001).

During periods when gradient-flux measurements were not running, $\mathrm{NH}_{3}$ concentration was measured as monthly averages at one height ( $1.5 \mathrm{~m}$ above ground) using a DELTA system (DEnuder for Long-Term Ammonia; Sutton et al., 2001). Here, $\mathrm{NH}_{3}$ was captured by the citric acid-coated inner surface of glass denuders after lateral molecular diffusion in a laminar flow of sampled ambient air, following the method by Ferm (1979). The monthly mean concentration was determined after extraction of the denuder following exposure in the field and chemical analysis of the $\mathrm{NH}_{4}^{+}$ concentration performed using an AMFIA (AMmonia Flow Injection Analysis) system (ECN, Petten, The Netherlands). These data were part of a wider network of 56 DELTA monitoring sites across Europe within the framework of the NitroEurope project (Sutton et al., 2007; Tang et al., 2009). The Oensingen DELTA $\mathrm{NH}_{3}$ data were thus used in the gapfilling procedure for the calculation of the annual $\mathrm{NH}_{3}$ exchange budget at this site (see Sect. 2.4).

\subsection{Inferences from micrometerological measurements and compensation point modeling}

\subsubsection{Basic principles of inferential modeling}

The surface/atmosphere transfer of $\mathrm{NH}_{3}$ may be conceptualized as an electrical analogue within a network of resistances characterizing transfer pathways through the canopy and between the surface and the atmosphere (Monteith and Unsworth, 1990; Thom, 1975). For depositing trace gases, micrometeorological flux measurements have traditionally provided experimental estimates of the canopy resistance $R_{c}$ as the difference between the inverse deposition velocity $V_{d}^{-1}$ (equal to the total resistance to deposition), and the sum of atmospheric aerodynamic and pseudo-laminar boundary layer resistances $\left(R_{a}+R_{b}\right)$ (Garland, 1977) (see Fig. A1a). Dry deposition models seek to predict $R_{c}$ from environmental and ecosystem drivers, with the objective of inferring the deposition flux $F_{\chi}$ as the product of concentration and deposition velocity, assuming that the canopy concentration is zero. Indeed, most regional atmospheric transport and deposition models still use a deposition-only, $R_{c}-V_{d}$ approach for $\mathrm{NH}_{3}$ (Simpson et al., 2003; Zhang et al., 2003; Erisman et al., 1994).

However, the soil/vegetation/atmosphere exchange of $\mathrm{NH}_{3}$ has long been shown to be clearly bi-directional (e.g. Dabney and Bouldin, 1990; Sutton et al., 1995a), as there exists a non-zero bulk canopy $\mathrm{NH}_{3}$ potential $\chi\left\{z_{0}^{\prime}\right\}$ (see Fig. A1b), allowing both deposition and emission to occur depending on the ambient atmospheric concentration $\chi\{z-d\}$. This is due to the occurrence of dissolved $\mathrm{NH}_{3}$ and $\mathrm{NH}_{4}^{+}$in the apoplastic fluid of leaves (Farquhar et al., $1980)$, characterised by a stomatal compensation point $\left(\chi_{s}\right)$, in leaf surface water films, and in the decaying plant material of a leaf litter on the ground (Nemitz et al., 2000; Mannheim et al., 1997). Second generation models based on the canopy compensation point $\left(\chi_{c}\right)$ concept (Sutton et al., 1998; Smith et al., 2000; Wu et al., 2009) have thus been developed. The potentials $\chi_{c}$ and $\chi\left\{z_{0}^{\prime}\right\}$ are conceptually equivalent, though the former is taken in this paper to represent a model (predictive) formalization of the latter, which is experimentally estimated from micrometeorological flux data. Both terms are effectively notional average (bulk) canopy concentrations.

\subsubsection{The single-layer canopy compensation point model}

The Sutton et al. (1998) single-layer $\chi_{c}$ model, also known as the $\chi_{s}-R_{w}$ model (Fig. A1b), predicts the net $\mathrm{NH}_{3}$ exchange as resulting from 1) bi-directional flux through plant stomates, impeded by the stomatal resistance $R_{s}$, and 2) the capture by leaf cuticles, surface water layers and other nonstomatal surfaces, collectively through the resistance $R_{w}$. The net exchange flux is modelled as:

$F_{\chi}=\frac{\chi_{c}-\chi\{z-d\}}{R_{a}\{z-d\}+R_{b}}$

where $\chi$ and $R_{a}$ are evaluated at a reference height $z-d$ (=1 $\mathrm{m}$ in the present study). Sutton et al. (1998) show that the resolution of the resistance network yields $\chi_{c}$ as:

$\chi_{c}=\frac{\frac{\chi\{z-d\}}{\left(R_{a}\{z-d\}+R_{b}\right)}+\frac{\chi_{s}}{R_{s}}}{\frac{1}{\left(R_{a}\{z-d\}+R_{b}\right)}+\frac{1}{R_{s}}+\frac{1}{R_{w}}} \quad\left(\equiv \chi\left\{z_{0}^{\prime}\right\}\right)$

The resistances $R_{a}$ and $R_{b}$ are relatively well characterised and readily calculated from micrometeorological measurements (e.g. Monteith and Unsworth, 1990; Garland, 1977): 
$R_{a}(z-d)=\frac{1}{k u_{*}}\left[\ln \left(\frac{z-d}{z_{0}}\right)-\psi_{H}\left(\frac{z-d}{L}\right)+\psi_{H}\left(\frac{z_{0}}{L}\right)\right]$

and

$R_{b}=\frac{1.45\left(\frac{z_{0} u_{*}}{v}\right)^{0.24}\left(\frac{v}{D}\right)^{0.8}}{u_{*}}$

where $z_{0}$ is the roughness length, $d+z_{0}$ being the notional height of momentum exchange and theoretical zero windspeed, $v$ is the kinematic viscosity of air and $D$ is the molecular diffusivity of $\mathrm{NH}_{3}$ in air.

\subsubsection{Parameterisations for $R_{s}, R_{w}$ and $\chi_{s}$}

Micrometeorological flux measurements made in background conditions at Oensingen were analysed in such a way as to derive the remaining unknowns in Eq. (3) i.e. $R_{s}, R_{w}$ and $\chi_{s}$, which were inferred from measured $\mathrm{NH}_{3}$ and water vapour concentrations and fluxes. The first step is the calculation of the bulk canopy $\mathrm{NH}_{3}$ concentration $\chi\left\{z_{0}^{\prime}\right\}$, which is given by a straightforward extrapolation from the reference height $(z-d)$ down to $z_{0}$ ':

$\chi\left\{z_{0}^{\prime}\right\}=\chi\{z-d\}+F_{\chi}\left(R_{a}\{z-d\}+R_{b}\right)$

The bulk stomatal resistance $\left(R_{S}\right)$ was evaluated for $\mathrm{H}_{2} \mathrm{O}$ from the measured latent heat flux $(\lambda E)$, which was a routine output of the CarboEurope-IP eddy covariance (EC) flux monitoring programme, alongside $u_{*}$, sensible heat flux $(H)$ and $\mathrm{CO}_{2}$ exchange (Ammann et al., 2007). In dry, daytime conditions most of the evapotranspiration flux $E$ may be assumed to issue from stomata, with close to negligible contributions from soil and leaf surface evaporation. Thus the vapour pressure deficit (vpd) at height $z_{0}^{\prime}$ bears a direct relationship to $E$ and $R_{S}$ such that (Thom, 1975; Monteith and Unsworth, 1990):

$R_{s}\left\{\mathrm{H}_{2} \mathrm{O}\right\}=\frac{\rho \varepsilon}{p} \frac{v p d}{E}=\frac{\rho \varepsilon}{p} \frac{\left(e_{\mathrm{sat}}\left\{T\left(z_{0}^{\prime}\right)\right\}-e\left\{z_{0}^{\prime}\right\}\right)}{E}$

where $\rho$ is air density, $p$ is atmospheric pressure, $\varepsilon$ is the ratio of the molecular weight of water to the mean molecular weight of dry air (18/29), and $e_{\text {sat }}\left\{T\left(z_{0}^{\prime}\right)\right\}$ and $e\left\{z_{0}^{\prime}\right\}$ are the saturation water vapour pressure and actual vapour pressure at height $z_{0}^{\prime}$. The surface potentials $T\left\{z_{0}^{\prime}\right\}$ and $e\left\{z_{0}^{\prime}\right\}$ are estimated using a similar extrapolation to that for $\mathrm{NH}_{3}$ (Eq. 6):

$T\left\{z_{0}^{\prime}\right\}=T\{z-d\}+\frac{H}{\rho C_{p}}\left(R_{a}\{z-d\}+R_{b}\right)$

with $C_{p}$ the specific heat capacity of air, and,

$e\left\{z_{0}^{\prime}\right\}=e\{z-d\}+\frac{p E}{\rho \varepsilon}\left(R_{a}\{z-d\}+R_{b}\right)$

As stomatal resistance could only be evaluated experimentally in dry conditions, a light-response parameterisation of $R_{S}$, which has been applied extensively in the flux modeling literature (Baldocchi et al., 1987; Hicks et al., 1987; Erisman et al., 1994; Nemitz et al., 2001; Zhang et al., 2003), was used whenever no measured $R_{S}$ was available, e.g. after rain or in the early morning before dew had evaporated:

$R_{s}\left\{\mathrm{NH}_{3}\right\}=R_{s, \min }\left[1+\frac{b^{\prime}}{I_{p}}\right] /\left(f_{e} f_{w} f_{T} f_{s}\right)$

Here, $I_{p}$ is the photosynthetic radiation intensity, $b^{\prime}$ is an empirical constant, $R_{s, \min }$ is the minimum value of $R_{s}$ and the correction factors $f_{e}, f_{w}$ and $f_{T}$ account for the effects of increasing vpd, plant water stress and temperature, respectively (Jarvis, 1976), although $f_{w}$ was actually set to 1 in the absence of leaf water potential measurements. The stomatal resistance for $\mathrm{NH}_{3}$ differs from that for $\mathrm{H}_{2} \mathrm{O}$ by the ratio of their respective molecular diffusivities (Hicks et al., 1987; Wesely, 1989), which is accounted for in the last correction factor $f_{s}$. The $R_{s, \text { min }}$ and $b^{\prime}$ parameters were fitted independently and separately for each growth phase on both INT and EXT fields, as was the parameter $b_{e}$ needed in the calculation of the vpd stress factor $\left(f_{e}=1-b_{e} \cdot \mathrm{vpd}\right.$; Hicks et al., 1987). Note that $R_{s}$ in Eq. (10) is expressed on a unit leaf area basis; the bulk (canopy) stomatal resistance is scaled by the inverse leaf area index $\left(\mathrm{LAI}^{-1}\right)$.

From the knowledge of $\chi\left\{z_{0}^{\prime}\right\}$ and $R_{s}$, the terms $\chi_{s}$ and $R_{w}$ may be approached separately. In a similar fashion to previous studies (Nemitz et al., 2001, for a review), the non stomatal resistance $R_{w}$, also termed $R_{\text {ext }}$ (Erisman et al., 1994) or $R_{\text {cut }}$ (Hicks et al., 1987), was derived from night-time measurements, when $R_{s}$ may be assumed to be much larger than $R_{w}$ so that Eq. (3) simplifies to:

$R_{w}($ night $) \cong\left(R_{a}\{z-d\}+R_{b}\right) \frac{\chi\left\{z_{0}^{\prime}\right\}}{\chi\{z-d\}-\chi\left\{z_{0}^{\prime}\right\}}$

It should be noted that 1) $R_{w}$ may only be evaluated in this fashion if $\chi(z-d)>\chi\left\{z_{0}^{\prime}\right\}$, i.e. only in the case of deposition, lest $R_{w}$ be negative; and 2) $R_{w}$ is essentially equivalent, during night-time, to $R_{c}$ calculated as the residual between $R_{t}$ and $\left(R_{a}+R_{b}\right)$ in a canopy resistance framework. The use of a high night-time value for $R_{S}$ (e.g. $5000 \mathrm{~s} \mathrm{~m}^{-1}$ ) using Eq. (3), instead of the simplified Eq. (11), yields similar results for $R_{w}$.

In theory, $\chi_{s}$ could be obtained from Eq. (3) if experimental estimates of $\chi\left\{z_{0}^{\prime}\right\}, R_{s}$ and $R_{w}$ are available, but the combined potential error or noise in these terms would result in a high uncertainty for individual values of $\chi_{s}$. An option sometimes preferred (Flechard et al., 1999; Spindler et al., 2001; Nemitz et al., 2001), and also used here, consists in selecting individual flux measurement runs in dry conditions, when the exchange switches from deposition to emission, or vice versa, i.e. the net flux is close to zero. Under the hypotheses 1) that stomata are open, 2) that $R_{w}$ is very large, and 3 ) that therefore stomatal exchange may reasonably be expected to represent by far the major pathway, then $\chi_{s}$ may be approximated to $\chi\left\{z_{0}^{\prime}\right\}$, as estimated experimentally from Eq. (6). For those runs, the apoplastic $\left[\mathrm{NH}_{4}^{+}\right] /\left[\mathrm{H}^{+}\right]$ratio, 
termed $\Gamma_{s}$, which characterizes the emission potential of the plant leaves, though normalized for the effect of temperature on $\mathrm{NH}_{3}$ solubility in water, may be inferred from (Flechard et al., 1999):

$\Gamma_{s}=\frac{\chi_{s} \times 10^{-9}}{10^{4.1218-4507 / T\left\{z_{0}^{\prime}\right\}}} \chi_{s}$ in ppb and $T\left\{z_{0}^{\prime}\right\}$ in $K$

\subsection{Gap-filling and $\mathrm{NH}_{3}$ budget}

\subsubsection{Data management}

The annual budget of $\mathrm{NH}_{3}$ exchange was calculated by integrating background exchange and fertiliser-induced emission peaks separately, which has been done for $\mathrm{N}_{2} \mathrm{O}$ exchange at the same site (Flechard et al., 2005). The background vs. fertiliser events split has the merit of showing what the $\mathrm{NH}_{3}$ budget might have been in the absence of fertiliser applications. It is acknowledged, however, that fertilisation alters the $\mathrm{N}$ status of plants (total $\mathrm{N}$, substrate $\mathrm{N}$, and apoplastic $\mathrm{NH}_{4}^{+}$concentrations) (Riedo et al., 2002), and in the longer term affects background exchange through a raised $\chi_{s}$. A further justification for the split lies in the necessarily dynamic modeling of $\mathrm{NH}_{3}$ emission by slurry applied to soil, with a rapid depletion of an initial $\mathrm{NH}_{4}^{+}$pool (e.g. Génermont and Cellier, 1997), as opposed to the essentially static $\chi_{s}-R_{w}$ approach applied for background exchange. In the latter, the apoplastic $\mathrm{NH}_{4}^{+}$content is considered in a first approximation to be in a buffered equilibrium with the soil-plant system and roughly constant over longer time scales, although this has been disputed (Herrmann et al., 2009; Mattsson et al., 2009).

The measured surface concentration $\chi\left\{z_{0}^{\prime}\right\}$ was the criterion used to determine the end of the fertiliser-induced "disturbance", and the resumption of background conditions; the determination of the threshold is detailed in the "Results" section. Flux integration and annual budget calculation could be sensitive to this threshold to the extent that parameterisations derived for $\chi_{s}$ and $R_{w}$ from measured data are less influenced by concentrations and processes in the slurry layer, and more by plant physiology, canopy cycling and meteorological conditions, if the time elapsed since fertilisation is longer. By selecting data appropriately, one may hope to derive parameterisations that are suitable for background exchange at this (and other) site(s).

\subsubsection{Cumulative fluxes for background exchange}

Two methods were considered for deriving cumulative monthly, seasonal or annual budgets from the semicontinuous time series of measured half-hourly $\mathrm{NH}_{3}$ fluxes:

1) Arithmetic mean diurnal cycles of measured fluxes were computed for each month, leaving out data from fertiliser events as defined above, and the total monthly background flux was calculated by scaling up from the average flux and the number of background days in each month. This is statistically the least-biased estimate, provided that flux data coverage is high enough (e.g. $>50 \%$ ) and that gaps in the dataset are evenly distributed over time of day and season of year. However, experience has shown at this site (Ammann et al., 2007) that many (40\%) night-time fluxes have to be rejected because of low wind speeds $\left(<1 \mathrm{~m} \mathrm{~s}^{-1}\right)$ and breakdown of turbulence, which are not conducive to satisfactory flux-gradient or EC measurements. Further, there were no flux measurements during certain individual months (January, February and September 2007), and other months with reduced flux data coverage, precluding the calculation of a reliable annual budget on the basis of monthly fluxes.

2) The time series of actual (measured) $\mathrm{NH}_{3}$ fluxes was gap-filled using the $\chi_{s}-R_{w}$ canopy compensation point model parameterised specifically for this site (Sect. 2.3), and the cumulative flux was obtained directly from the gap-filled 30-min time series. Inferential modeling requires the knowledge of $\mathrm{NH}_{3}$ concentration at one height and of standard meteorological data such as air temperature, global radiation, relative humidity, and windspeed (or $u_{*}$ and $\mathrm{H}$ whenever available). During brief periods (a few hours to a few days) of interruption of the AiRRmonia monitors, $\mathrm{NH}_{3}$ concentration for each missing half-hour was taken from the mean diurnal course of $\mathrm{NH}_{3}$ during the month. For extended periods ( $>1$ month) of AiRRmonia downtime, the monthly (mean) $\mathrm{NH}_{3}$ concentration as measured by the DELTA system was used as input to the model.

Method 2) was deemed the least-biased method, and therefore used for budget calculations, primarily because of the lack of flux measurements in night-time and stable conditions (thermal stratification) and in winter. Method 1) (scaling up from mean diurnal cycles) was nonetheless applied to calculate monthly fluxes for the purpose of comparison with method 2) (measured and model gap-filled).

\subsubsection{Time integration of manure-induced emission fluxes}

Emission fluxes measured by the AGM after slurry application were first corrected to account for errors arising from the horizontal advection of $\mathrm{NH}_{3}$ on the field (Loubet et al., 2001) and fetch restrictions (Neftel et al., 2008). By applying the Kormann-Meixner footprint model (Kormann and Meixner, 2001; Neftel et al., 2008) for each half-hourly measurement, Spirig et al. (2010) showed that the AGM underestimated the true (surface) emission fluxes at this site by on average $34 \%$ (range: $14-59 \%$ ), and measured AGM fluxes were corrected accordingly. The FIDES model (Flux Interpretation by Dispersion and Echange over Short range) by Loubet et al. (2001) was shown to yield comparable results. 
To fill data gaps in the time series of footprint-corrected fluxes during slurry events, an empirical estimate of the canopy potential $\chi\left\{z_{0}^{\prime}\right\}$ was used as a predictor of the emission strength. Since ambient $\mathrm{NH}_{3}$ concentration measurements at the reference height were available most of the time, as were the standard meteorological variables required to compute estimates of $R_{a}$ and $R_{b}$, fluxes could be approached from the potential difference between $z_{0}^{\prime}$ and $(z-d)$ and the sum of atmospheric resistances (Eq. 2). The procedure is described in detail in Spirig et al. (2010).

\section{Results}

\subsection{Seasonal patterns in measured fluxes and stomatal resistance}

The overall picture of $\mathrm{NH}_{3}$ exchange from July 2006 through October 2007 is dominated by sharp and relatively shortlived emission peaks induced by six applications of cattle slurry onto the INT plot, which took place in July, September and October 2006, and in April, July and October 2007 (Fig. 1). Individual (half-hourly) measured fluxes reached values above $+50 \mu \mathrm{g} \mathrm{NH}_{3} \mathrm{~m}^{-2} \mathrm{~s}^{-1}$ (or $1.2 \mathrm{~kg} \mathrm{Nha}^{-1} \mathrm{hr}^{-1}$ ) during the first few hours following the spreading of liquid manure onto short $(<10 \mathrm{~cm})$ grassland, but the emission was usually reduced to a few $100 \mathrm{ng} \mathrm{NH}_{3} \mathrm{~m}^{-2} \mathrm{~s}^{-1}$ within a few days of fertilising. For the rest of each grass growth phase until the next cut, background exchange on the INT field was either dominated by deposition (negative fluxes), as in 2006, or characterised in 2007 by bi-directional fluxes mostly in the range -100 to $+100 \mathrm{ng} \mathrm{NH}_{3} \mathrm{~m}^{-2} \mathrm{~s}^{-1}$ (Fig. 1). The fluxes measured on the EXT field during two short spells $(6 \mathrm{~d}$ in July 2006 and 16 d in September 2006) were similar in magnitude to background fluxes on the INT field, with mostly deposition to the canopy and few emission fluxes greater than $+100 \mathrm{ng} \mathrm{NH}_{3} \mathrm{~m}^{-2} \mathrm{~s}^{-1}$. Grass cuts do not appear to have led to enhanced $\mathrm{NH}_{3}$ emissions on either field on any occasion during the first 2-3 d when grass lay drying on the ground or was being processed into hay or silage.

Bulk stomatal resistance, derived from EC water vapour flux measurements (Eq. 7) in dry daytime conditions, responded as expected to grass cuts and the subsequent regrowth, mirroring temporal changes in LAI (Fig. 1, bottom frames). There were also signs in the second half of July 2006 of heat and water stresses, leading to elevated transfer resistances. Modelled $R_{S}$ (Eq. 10) is shown alongside measured values; fitted parameter values for $R_{s, \min }, b^{\prime}$ and $b_{e}$ averaged $57 \mathrm{~s} \mathrm{~m}^{-1}, 97 \mathrm{~W} \mathrm{~m}^{-2}$ and $0.24 \mathrm{kPa}^{-1}$ on the INT field, and $46 \mathrm{~s} \mathrm{~m}^{-1}, 92 \mathrm{~W} \mathrm{~m}^{-2}$ and $0.13 \mathrm{kPa}^{-1}$ on the EXT field, respectively.

During the transition phase following each slurry event, when $\mathrm{NH}_{3}$ fluxes and concentrations gradually reverted to pre-fertilisation levels, the ambient $\mathrm{NH}_{3}$ concentration $\chi\{1 \mathrm{~m}\}$ declined much more rapidly than did the canopy concentration $\chi\left\{z_{0}^{\prime}\right\}$. Within 2-5d following the spreading of liquid manure, $\chi\{1 \mathrm{~m}\}$ had stabilised at background levels (Fig. 2a), albeit with typical diurnal variations, whereas the time course of $\chi\left\{z_{0}^{\prime}\right\}$ clearly shows a much longerlasting memory effect, following the initial surge upwards of $1000 \mu \mathrm{g} \mathrm{NH}_{3} \mathrm{~m}^{-3}$. A visual analysis of Fig. 2b suggests that the effect of the applied slurry on the canopy concentration wears off only after 10-20 d. A threshold of $20 \mathrm{~d}$ was thus chosen for all events to distinguish background conditions from fertilisation events.

Figure 2c further illustrates the exponential decay over time of the emission potential of the canopy following spreading, characterised by the bulk $\left[\mathrm{NH}_{4}^{+}\right] /\left[\mathrm{H}^{+}\right]$ratio of the surface (termed $\Gamma_{\text {canopy }}$ ) that one may derive from estimated $\chi\left\{z_{0}^{\prime}\right\}$ using Eq. (12). The $\Gamma_{\text {canopy }}$ term is initially dominated by the manure layer lying on leaves and soil, rather than by the apoplast potential $\Gamma_{s}$. The linear regressions for the 6 spreading events of $\log \left(\Gamma_{\text {canopy }}\right)$ vs. $\log ($ time $)$ are broadly consistent with the initial values of $\Gamma_{\text {slurry }}$, calculated from the chemical analysis of tank slurry and ranging from $8.5 \times 10^{5}$ to $6.3 \times 10^{6}$, with slurry $\left[\mathrm{NH}_{4}^{+}\right]$ranging from 0.057 to $0.104 \mathrm{~mol} \mathrm{l}^{-1}$, and $\mathrm{pH}$ ranging from 7.1 to 7.9 (Spirig et al., 2010).

The analysis of mean diurnal cycles in ambient $\mathrm{NH}_{3}$ concentrations and fluxes for each month of the monitoring period (background conditions only) reveals key aspects of the combined meteorological and plant physiological control of $\mathrm{NH}_{3}$ exchange (Fig. 3). Diurnal concentration profiles typically showed an asymmetrical morning peak during the summer months in 2006, with a sharp rise peaking at around 08:00 CET in July, 09:00 in August, 10:30 in September, followed by a slow decline until around 20:00, and no variations until sunrise the next morning (Fig. 3, top frame). In 2007, the concentrations also peaked asymmetrically in the morning in April, June and August. By contrast, the diurnal variation was more akin to a sine wave with smoother variations in October, November and December 2006 and March, May and July 2007, with a daily maximum centered around noon or early afternoon and a night-time minimum. Concentrations were considerably higher in 2006 than in 2007, peaking at $10 \mathrm{\mu g} \mathrm{m}^{-3}$ during the day, with night-time values between 2 and $4 \mu \mathrm{g} \mathrm{m}^{-3}$ for much of the second half of 2006 , while in 2007 concentrations reached only $4 \mu \mathrm{g} \mathrm{m}^{-3}$ daytime maxima and were otherwise below $2 \mu \mathrm{g} \mathrm{m}^{-3}$ for much of the year.

As a result, diurnal flux patterns (Fig. 3, bottom frame) indicate predominant deposition throughout the day in 2006, consistent with ambient concentrations being higher than the canopy compensation point, while there were systematic daytime emissions (10:00-18:00 CET) in spring and early summer 2007, consistent with $\chi_{c}$ being higher than ambient $\mathrm{NH}_{3}$. The low magnitude of mean daytime emissions in 2007, typically $10-30 \mathrm{ng} \mathrm{NH}_{3} \mathrm{~m}^{-2} \mathrm{~s}^{-1}$, and the consistent sink activity in 2006 and during night-time and winter, are 
(

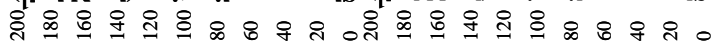

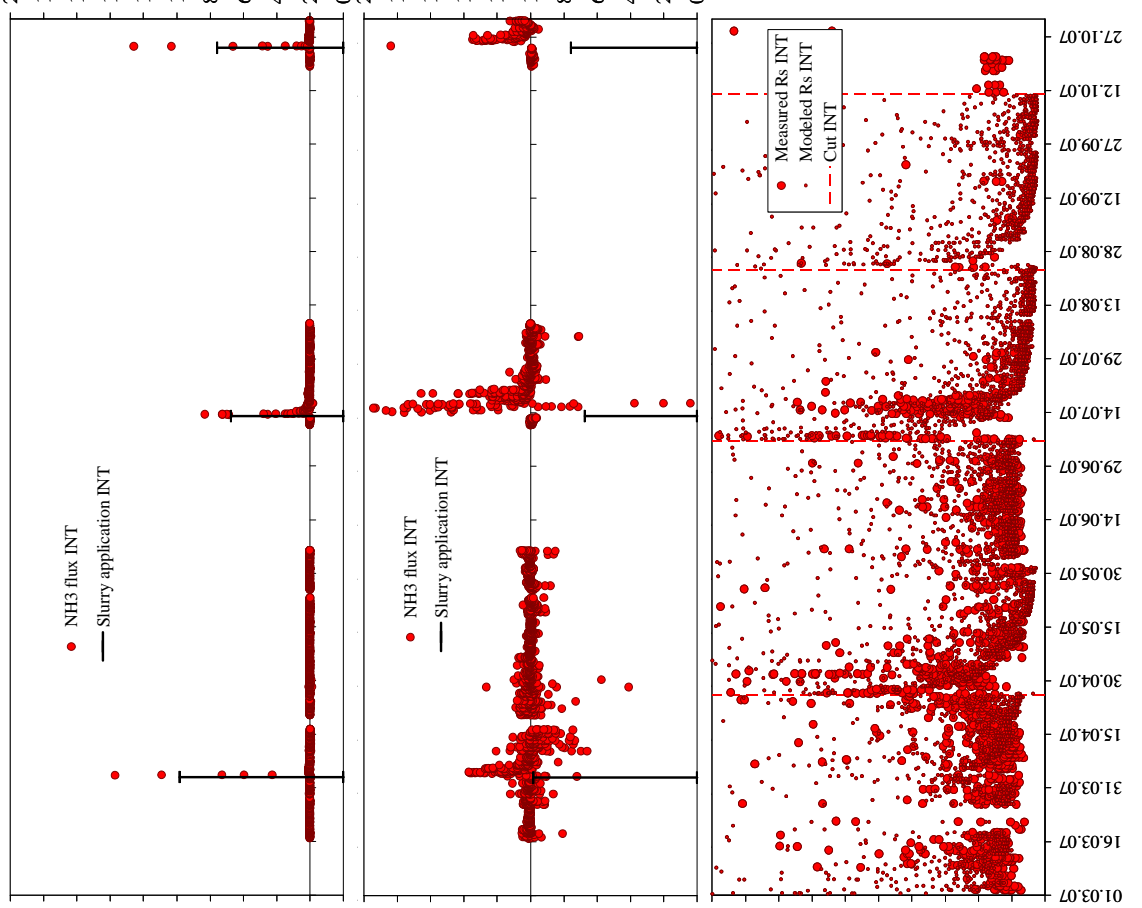

尊 \&

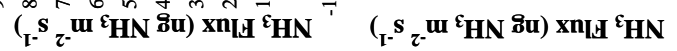
( ${ }^{-} \mathbf{u}$ s) $\mathbf{O}^{\boldsymbol{z}} \mathbf{H}^{\mathrm{s}} \boldsymbol{d}$

('

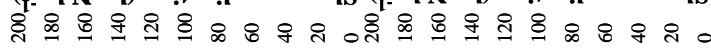

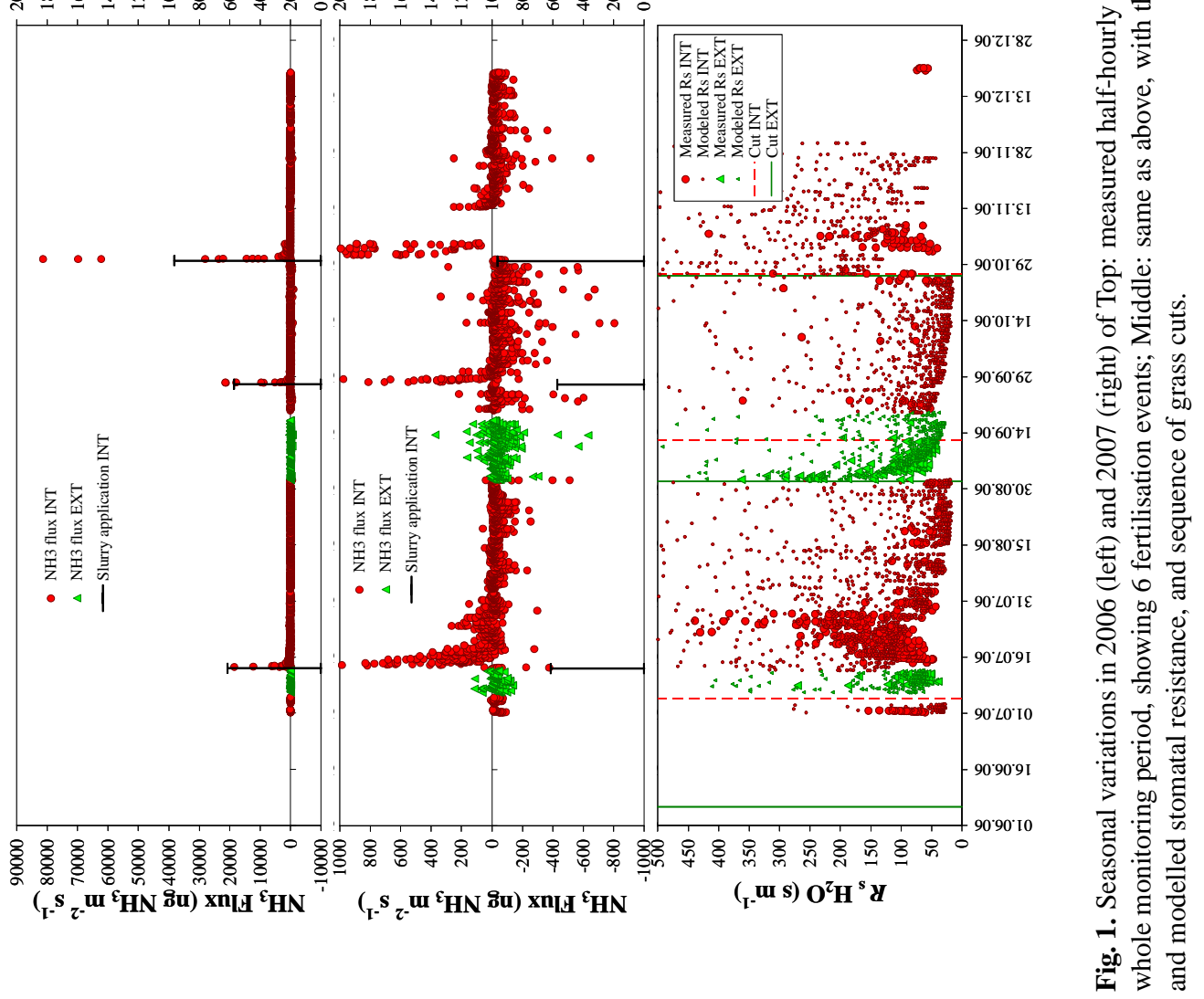




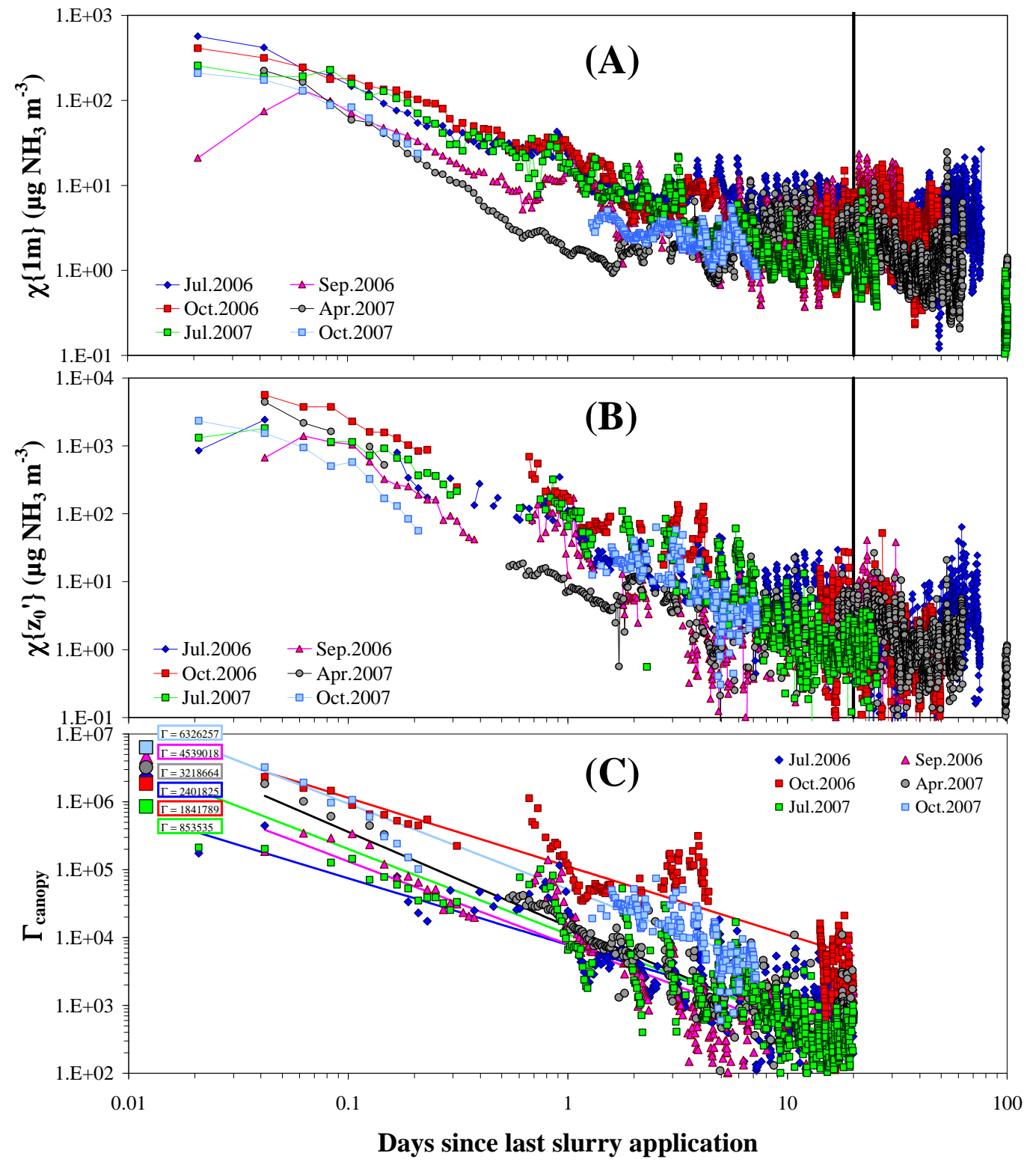

Fig. 2. Temporal dynamics of $\mathrm{NH}_{3}$ concentration following cattle slurry spreading, (A) at the reference height in the surface layer $(z-d=1 \mathrm{~m})$; (B) at canopy level $\chi\left\{z_{0}^{\prime}\right\}$; and (C) bulk canopy emission potential $\Gamma_{\text {canopy }}$, derived from $\chi\left\{z_{0}^{\prime}\right\}$, for 6 fertilisation events. Initial values of $\Gamma_{\text {slurry }}$ are shown in (C) for comparison with subsequent micrometeorological estimates of $\Gamma_{\text {canopy }}$ and the log-log regression thereof vs. time elapsed. The vertical line at day 20 is the arbitrary threshold chosen to distinguish emission events from background exchange.

however clear indicators that over the whole year, the grassland canopy was a net sink in background conditions.

\subsection{Parameterisation of the external leaf surface resistance}

Values of $R_{w}$ estimated during night-time according to Eq. (11) showed as expected a clear relationship to surface relative humidity ( $\left.\mathrm{RH}\left\{z_{0}^{\prime}\right\}\right)$ (Fig. 4, top frame), as water films on leaf cuticles, stems and other non-stomatal surfaces in the canopy are known sinks for atmospheric $\mathrm{NH}_{3}$ (Flechard et al., 1999). The shape of the relationship to $\mathrm{RH}\left\{z_{0}^{\prime}\right\}$ was approximated to an exponential decay with lowest $R_{w}$ values at $100 \%$ relative humidity, analogous to the form suggested by Sutton et al. (1998):

$$
R_{w}=R_{w, \min } \times \exp ^{\alpha \times\left(100-\mathrm{RH}\left\{z_{0}^{\prime}\right\}\right)}
$$




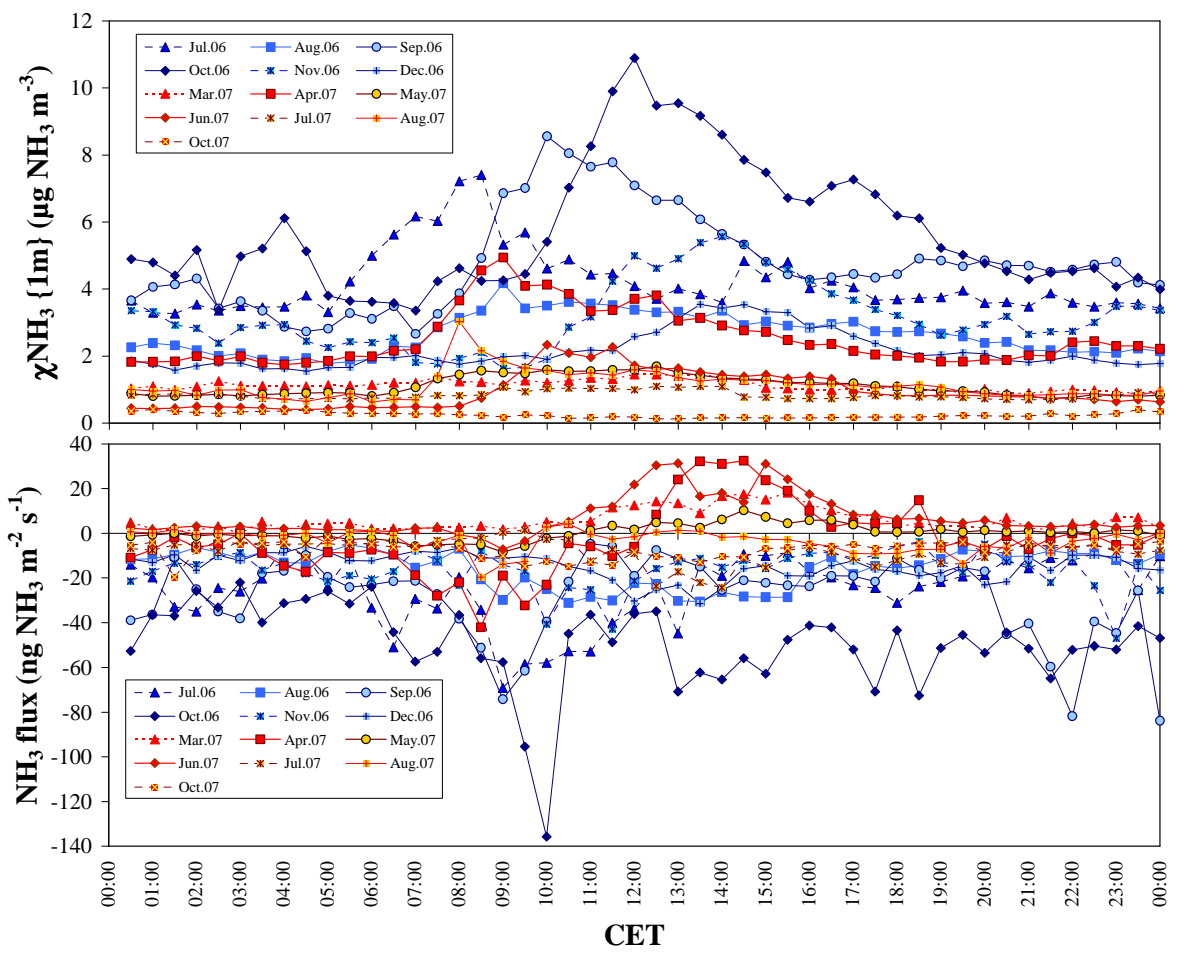

Fig. 3. Mean diurnal variations of $\mathrm{NH}_{3}$ concentration (top) and exchange flux (bottom) in background conditions (all data measured within the 20-d period following slurry applications were removed from the dataset). CET: Central European Time.
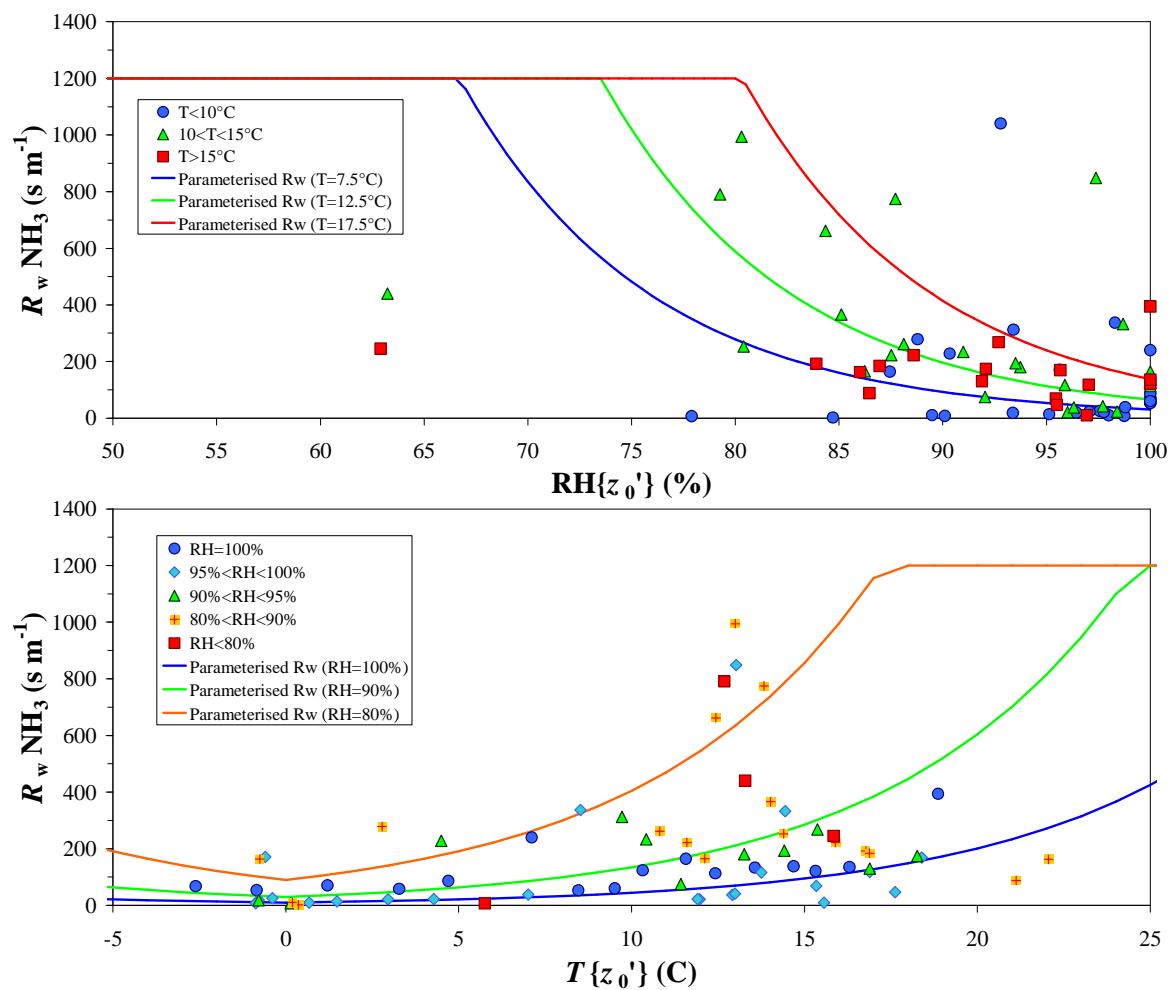

Fig. 4. Relationship of the non-stomatal resistance $R_{w}$ to relative humidity and temperature at the surface $\left(z_{0}^{\prime}\right)$. Symbols are median values of measured (night-time) data binned into classes of temperature and relative humidity, with data screened to remove periods of strong nocturnal atmospheric stability $\left(R_{a}+R_{b}>200 \mathrm{~s} \mathrm{~m}^{-1} ; u_{*}<0.1 \mathrm{~m} \mathrm{~s}^{-1}\right)$. Lines show the proposed parameterisation following Eq. (14). 
However, the data additionally showed a clear control of $R_{w}$ by the surface temperature $T\left\{z_{0}^{\prime}\right\}$; for a given surface relative humidity, $R_{w}$ tended to increase exponentially with temperature above $0^{\circ} \mathrm{C}$ (Fig. 4, bottom frame). Although there is substantial scatter in the data, the measurements show unequivocally the combined influences of both $T$ and $\mathrm{RH}$ in regulating non-stomatal resistance, which may be parameterised as follows:

$$
\begin{aligned}
R_{w} & =\min \left(R_{w, \max }, R_{w, \min } \times \exp ^{\alpha \times\left(100-\mathrm{RH}\left\{z_{0}^{\prime}\right\}\right)}\right. \\
& \left.\times \exp ^{\beta \times \operatorname{Abs}\left(T\left\{z_{0}^{\prime}\right\}\right)}\right)
\end{aligned}
$$

Here, $R_{w}$ is capped at $R_{w, \max }=1200 \mathrm{~s} \mathrm{~m}^{-1}$ in a similar fashion to Nemitz et al. (2000), while the minimum resistance is $R_{w, \min }=10 \mathrm{~s} \mathrm{~m}^{-1}$, the coefficients $\alpha=0.11$ and $\beta=0.15^{\circ} \mathrm{C}^{-1}$ with $T\left\{z_{0}^{\prime}\right\}$ expressed in Celsius.

\subsection{Micrometeorological estimates of $\Gamma_{s}$}

The analysis of flux reversal occurrences (deposition to emission or vice-versa) in dry and mostly daytime conditions yields estimates of $\Gamma_{s}$ (Eq. 12) for the INT field in the range 150-4000 (Fig. 5), with a median of 620 and an arithmetic mean value of $875(N=64)$. Values were not significantly different for measurements made in the EXT field in 2006, with a range of 220-1400, a median of 585 and an average of $659(N=12)$. These estimates were obtained from flux data selected using a surface relative humidity threshold of $81 \%$ to distinguish "dry" from "wet" conditions, as this corresponds to the deliquescence point of ammonium sulphate salts present on leaf cuticles (Flechard et al., 1999).

Given the necessary data selection process (dry, background conditions only), there were very few or no $\Gamma_{s}$ estimates for night-time, early morning, autumn, winter, as well as during the days following fertilisation, so that diurnal and seasonal variations were difficult to assess. As the grass was wet most mornings due to dewfall, most estimates of $\Gamma_{s}$ were obtained from 10:00 CET onwards (Fig. 5), after evaporation of leaf surface water films. No systematic diurnal cycle in $\Gamma_{s}$ can be detected in Fig. 5, although most $\Gamma_{s}$ values above 1000 were measured in the interval 10:30-18:00 CET. There were no clear seasonal patterns or event-related influences (cuts, fertilisation). Further, very few estimates of $\Gamma_{s}$ were obtained in 2006 as the exchange in the INT field was then dominated by deposition (Fig. 1) with therefore very few flux sign reversals.

\subsection{Annual $\mathrm{NH}_{3}$ budget}

An observation-based annual $\mathrm{NH}_{3}$ budget was calculated for the INT field following the gap-filling procedure as described in Sect. 2.4 and in Spirig et al. (2010). As there were no clear differences, between the EXT and INT fields during background phases, in flux patterns (Fig. 1) and stomatal compensation points (Fig. 5), and since fluxes could only be mea-

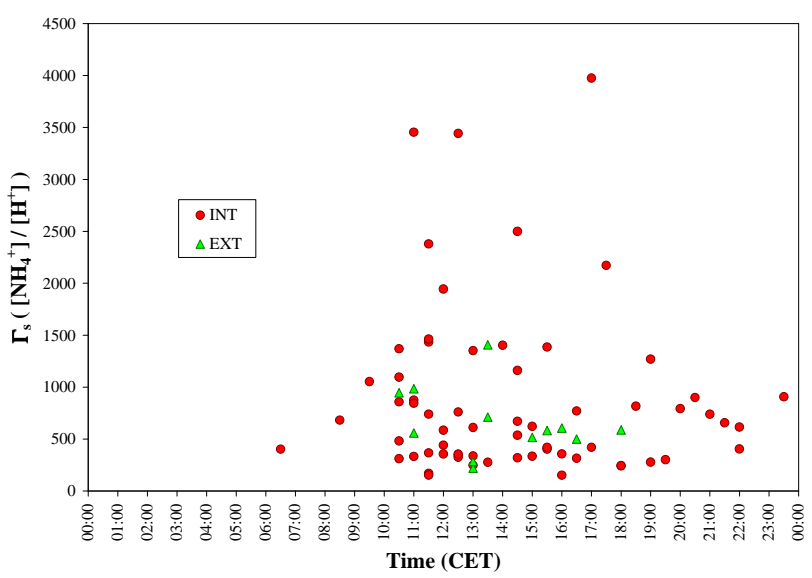

Fig. 5. Apoplastic $\Gamma_{S}$ ratio estimated from micrometeorological flux measurements (Eqs. 6 and 12), shown as a function of time of day.

sured on one of the two fields at a time, the two datasets were merged to calculate the cumulative background component of the INT budget. Modeled $R_{w}$ was calculated according to Eq. (14), and $\chi_{s}$ was computed on the basis of Eq. (12) using the median $\Gamma_{s}$ values of 620 and 585 for the INT and EXT fields, respectively, for the whole monitoring period. For slurry-induced emission events, gap-filling was achieved by using an interpolation of $\Gamma_{\text {canopy }}$ for the first few hours and days following manure application (Spirig et al., 2010).

The $\mathrm{NH}_{3}$ budget for the period July 2006 through October 2007 was $+27.2 \mathrm{~kg} \mathrm{Nha}^{-1}$, with a cumulative gross $\mathrm{NH}_{3}$ emission by 6 slurry applications of $+30.4 \mathrm{~kg} \mathrm{Nha}^{-1}$ and a net uptake of $-3.2 \mathrm{~kg} \mathrm{Nha}^{-1}$ in background exchange (Fig. 6). For the one-year interval 1 July 2006 to 30 June 2007, which included only four slurry events, and during which flux data capture was better, the net budget was $+17.0 \mathrm{~kg} \mathrm{Nha}^{-1} \mathrm{yr}^{-1}$ with slurry-induced $\mathrm{NH}_{3}$ emissions of $+20.0 \mathrm{~kg} \mathrm{Nha}^{-1} \mathrm{yr}^{-1}$ and background dry deposition of $-3.0 \mathrm{~kg} \mathrm{Nha}^{-1} \mathrm{yr}^{-1}$.

Cumulative fluxes obtained from gap-filled flux time series are compared in Fig. 7 with data scaled up from measured average diurnal cycles on a monthly basis. For background exchange (Fig. 7a), the scaling up from diurnal cycles overestimates monthly deposition by $50 \%$ overall. For total exchange (Fig. 7b), including also manure application events, the cumulative net emission is only $3 \%$ higher than that given by the gap-filled time series, but the apparent overall agreement conceals large discrepancies for given months. For example, in July 2006, the mean diurnal cycle approach underestimates total emission by more than half, as fluxes during the first $2 \mathrm{~h}$ after slurry spreading on 13 July could not be measured reliably due to $\mathrm{NH}_{3}$ concentrations exceeding the upper detection limit of the instrument (Spirig et al., 2010), which induced a large underestimation of daytime monthly mean fluxes. In October 2006, the measurement 


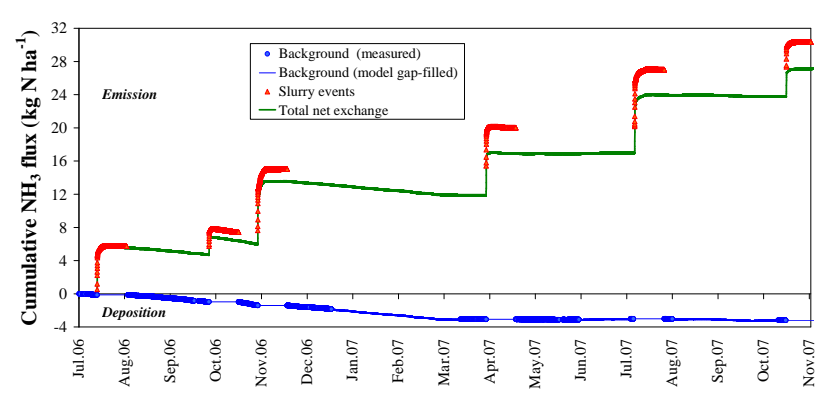

Fig. 6. Cumulative 17-month $\mathrm{NH}_{3}$ exchange with contributions from background exchange and slurry application events.

period mostly focused on the first few days following the application of slurry and thus background fluxes were underrepresented in the monthly dataset; this statistical bias meant that the diurnal cycle approach over-estimated the monthly flux by a factor of 2.6. This demonstrates the importance of careful, process-based, gap-filling procedures for the calculation of annual budgets, for both background exchange and peak emission events.

\section{Discussion}

\subsection{Compensation point modeling of $\mathrm{NH}_{3}$ exchange}

\subsubsection{Ammonia emission potential: apoplast vs. other canopy sources}

There have been numerous measurements and micrometeorological estimates of the apoplastic $\Gamma_{s}$ ratio in European grasslands over the last $10 \mathrm{yr}$, yet a current challenge in the $\mathrm{NH}_{3}$ emission/deposition modeling community remains to understand and predict temporal and spatial variations in $\Gamma_{s}$ for application in regional-scale atmospheric models. Total foliar $\mathrm{N}$ and $\mathrm{NH}_{4}^{+}$content and the stomatal compensation point have been shown to increase with either elevated atmospheric deposition in semi-natural systems, or with fertilisation level in agricultural environments (Pitcairn et al., 1998; Mattsson and Schjoerring, 2002; Herrmann et al., 2001), so that measurements of $\Gamma_{s}$ at any one site cannot be applied to all grasslands across the countryside. Ecosystem modeling may ultimately provide a sound basis for predicting stomatal compensation points not only for grasslands (Riedo et al., 2002) but also for a wider range of ecosystems, and validation measurements are needed.

By contrast to the direct measurement of $\mathrm{NH}_{4}^{+}$and $\mathrm{H}^{+}$ concentrations after extraction of the apoplastic fluid (e.g. Mattsson et al., 2009), we present micrometeorological estimates of $\Gamma_{s}$ based on the assumption that under selected dry conditions, most of the exchange takes place between stomata and the atmosphere (Sect. 2.3.3). The definition of a "dry" surface is thus a critical step in deriving $\Gamma_{s}$. Fig-

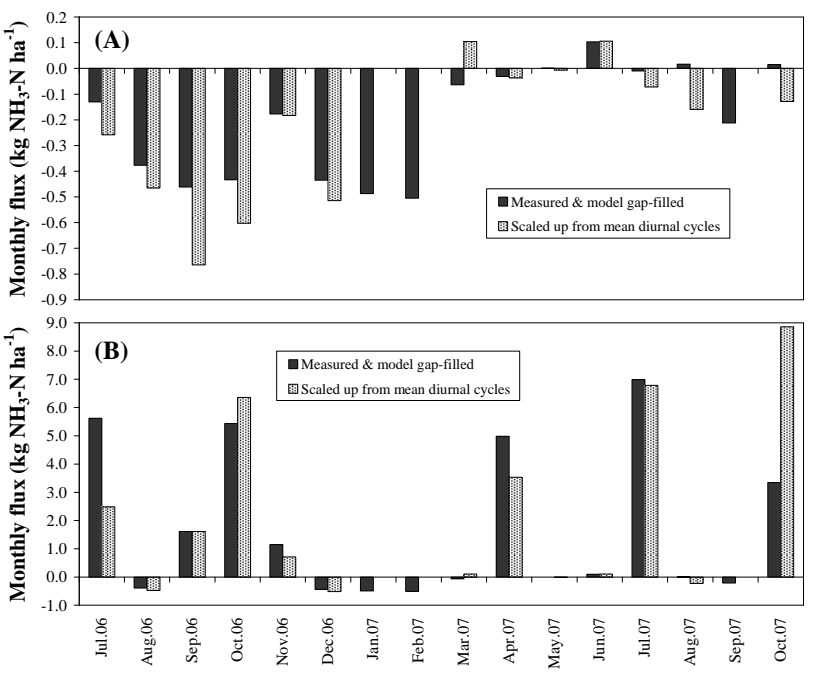

Fig. 7. Effect of flux integration method on monthly $\mathrm{NH}_{3}$ budgets. (A) background exchange only; (B) total fluxes (background exchange and slurry events).

ure 8 presents the sensitivity of the mean $\Gamma_{s}$ to the threshold for $\mathrm{RH}\left\{z_{0}^{\prime}\right\}$ used in selecting micrometeorological flux data, which by default is set to $81 \%$. For the INT data, the median $\Gamma_{s}$ increases from 420 at a threshold of $70 \%$, to 620 at $81 \%$, to 686 at $90 \%$ (a slope of $14 \Gamma_{s}$ units for each additional $1 \%$ in the threshold). This means that a greater stomatal source strength is required to overcome an increasing leaf surface sink capacity as relative humidity and the cuticular water film thickness both increase (Burkhardt et al., 2009). For the EXT field, no trend is visible as most data points were measured in very dry conditions at RH below $70 \%$. The sensitivity of the cumulated background flux, which is based on measured flux data and gap-filled with the $\chi_{s}-R_{w}$ model, is very low, as the overall net deposition flux increases by $9 \%$ for a threshold of $70 \%$, and decreases by only $3 \%$ for a threshold of $90 \%$, relative to the base run with a threshold of $81 \%$ (Fig. 8).

The median $\Gamma_{s}$ value of 620 for the INT field at Oensingen is rather at the low end of estimates for intensively managed grasslands found in the literature. Over a fertilised pasture at Zegveld in The Netherlands, Plantaz (1998) derived an apoplastic $\mathrm{NH}_{4}^{+}$concentration of $775 \mu \mathrm{M}$, equivalent to $\Gamma_{s}=4900$ with a pH of 6.8 , for conditions outside fertilisation events. Estimates of apoplastic $\mathrm{NH}_{4}^{+}$concentration obtained by Mosquera et al. (2001) at the Schagerbrug site in the Netherlands, using the apoplastic extraction technique, ranged over two orders of magnitude up to $6000 \mu \mathrm{M}$, equivalent to $\Gamma_{s}=6000$ with a $\mathrm{pH}$ of 6 . Wichink Kruit et al. (2007) derived an apoplastic $\Gamma_{s}=2200$ over grassland, which was unfertilised but located in an area of intensive agriculture in the Southern Netherlands, where atmospheric N deposition is high. Over cut grassland at Burrington Moor in the UK, Sutton et al. (1997) estimated a value of $\Gamma_{s}=1300$ before cutting, and a value of $\Gamma_{s}=10000$ after cutting. Similarly, 


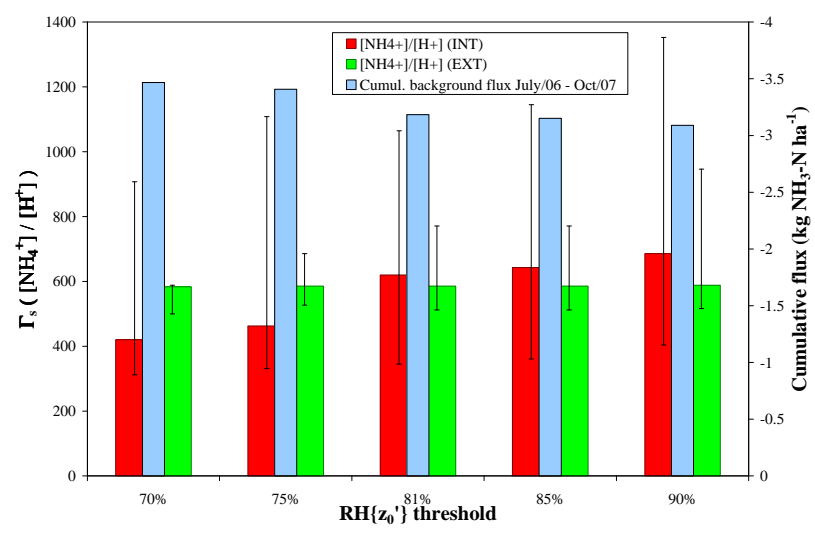

Fig. 8. Sensitivity of the median $\Gamma_{S}$ estimate to the relative humidity threshold used for the selection of "dry" surface conditions (vertical bars indicate 25th and 75th percentiles), and effect on the cumulative background exchange calculated using (model) gap-filled fluxes.

Milford (2004) estimated a "pre-cut" and winter $\Gamma_{s}$ of 630, an increasing "post-cut" $\Gamma_{s}$ up to a "post-fertilisation" (ammonium nitrate pellets) level of 28000 , and a "grazing" $\Gamma_{s}$ of 4000. The UK-CBED regional atmospheric deposition model (Smith et al., 2000) assumes a constant $\Gamma_{s}$ value of 3800 for all managed and improved grasslands.

By comparison, over unfertilised, semi-natural grassland at Melpitz in Eastern Germany, Spindler et al. (2001) derive $\Gamma_{s}$ in the range 150-1000. Over unimproved, extensive moorland at Auchencorth Moss in Southern Scotland, Flechard et al. (1999) measured predominantly deposition fluxes, although there were also occasional emissions, which were a consequence of an apoplastic $\Gamma_{s}$ ratio of 180 . Likewise, over semi-arid extensive grassland in Hungary, Horváth et al. (2005) found a background $\Gamma_{s}$ of around 100.

The contrast between published $\Gamma_{s}$ values for fertilised and unfertilised grasslands suggest a strong influence of added $\mathrm{N}$ on the foliar emission potential. It is logical to assume that some of the $\mathrm{NH}_{4}^{+}$in slurry that percolates and is adsorbed to soil particles will eventually be taken up by roots, migrate upwards to the apoplast and participate in stomatamediated exchange. However, the effect may not be as significant, nor as long-lasting, as may be expected on the basis of previous studies. New research demonstrates a rapid increase of $\Gamma_{s}$ in response to mineral fertiliser application, but this is followed by an exponential decrease of $\Gamma_{s}$ over $10 \mathrm{~d}$ back to pre-fertilisation levels (Mattsson et al., 2009; Loubet et al., 2002). Further, estimates of $\Gamma_{s}$ derived from micrometeorological flux measurements made above a canopy integrate the net effect of all component parts of the ecosystem. Thus the canopy compensation point $\chi_{c}$ is only a fair reflection of the stomatal compensation point $\chi_{s}$ if other emission sources within the canopy, e.g. soil and litter, as well as deposition pathways, may be considered negligible at a given point in time. It is increasingly recognised that some of the highest estimates of $\Gamma_{s}(>5000-10000)$ originally derived in some studies were biased upwards by emission potentials in the leaf litter (Burkhardt et al., 2009), in urine and dung on the soil surface in grazed systems (Milford, 2004), or in the remains of fertiliser some time after its field application (Harper et al., 2000). By filtering out slurry events from background exchange, this study seeks to provide an unbiased estimate of the emission potential of grassland per se, which might therefore appear lower than previously believed. The $\Gamma_{s}$ estimates at Oensingen (Fig. 5) are nonetheless thoroughly compatible with the range of values 200 2000 measured using the vacuum infiltration technique by van Hove et al. (2002) in Lolium perenne L. at Wageningen in the Netherlands, and with the mean value of 305 by Mattsson et al. (2009), and a range of 100-600 (Personne et al., 2009), at Braunschweig in Germany. The Oensingen $\Gamma_{s}$ estimates are substantially higher than at another cut grassland in Switzerland at Kerzersmoos (Herrmann et al., 2001), where $\Gamma_{s}$ ranged from 50 to 100 ; the lower mineral fertilisation rates of 80 to $160 \mathrm{~kg} \mathrm{Nha}^{-1} \mathrm{yr}^{-1}$ (vs. $>200 \mathrm{~kg} \mathrm{Nha}^{-1} \mathrm{yr}^{-1}$ at Oensingen) may be responsible in part for the difference.

Contrary to expectation no significant difference in $\Gamma_{s}$ could be detected between the INT and EXT treatments at Oensingen. However, the experiment was not designed with this objective in mind, with $\mathrm{NH}_{3}$ fluxes being measured on the INT field most of the time and on the EXT field on only two occasions in July (1 week) and September 2006 ( 2.5 weeks). Indeed, most estimates of $\Gamma_{s}$ for the EXT field were obtained in September 2006, a few days after the EXT field had been cut (Fig. 1), and thus $\Gamma_{s}$ derived from micrometeorological fluxes may not have reflected the sole foliar emission potential, but also a contribution by the leaf litter following the removal of grass (Milford, 2004; Burkhardt et al., 2009).

Light diurnal fluctuations in $\Gamma_{s}$ have been demonstrated in grassland using the apoplast vaccuum infiltration technique (Herrmann et al., 2009), with highest values occurring around noon, although diurnal changes were overshadowed by day-to-day dynamics related to management (cut, fertilisation). The stomatal compensation point model of Wu et al. (2009) predicts a strong $\Gamma_{s}$ peak in mid-afternoon and a night-time/early morning minimum, which are mostly driven by $\mathrm{pH}$ changes. At Oensingen, the analysis of diurnal variations in $\Gamma_{s}$ (Fig. 5) was inconclusive, in part because the micrometeorological data selection procedure (dry conditions only; stomata open; change in flux direction) results in few $\Gamma_{s}$ estimates being available overall and especially for night-time. Also, potential seasonal variations in $\Gamma_{s}$ (van Hove et al., 2002) make the interpretation of Fig. 5 rather difficult, as data for all seasons are pooled together. An alternative analysis (data not shown), where the diurnal variations of the (dimensionless) ratio of $\Gamma_{s}$ to the daily, weekly or monthly mean $\Gamma_{s}$ were investigated, did not reveal any significant patterns. The wide range of values in 
Fig. 5, with daytime maximum of up to 2000-4000, and late morning or early evening values below 500, is likely a reflection of seasonal variations rather than of diurnal changes. Seasonal dynamics themselves were difficult to assess, because micrometeorologically derived $\Gamma_{s}$ data were unevenly distributed through the year, with few estimates during the wetter months.

\subsubsection{Vertical distribution of sources and sinks in the canopy}

Recent advances in $\mathrm{NH}_{3}$ exchange modeling have sought to quantify the contributions of the soil, leaf litter, fertiliser or manure, and grazing animal excreta, as well as the stomatal emission potential of grassland (Riedo et al., 2002; Personne et al., 2009) and other agricultural crops, such as oilseed rape (Nemitz et al., 2000, 2001), wheat (Nemitz et al., 2001) and soybean (Wu et al., 2009; Walker et al., 2006). Such models recognise that, even in relatively short $(<1 \mathrm{~m})$, but rather closed canopies, turbulent transfer rates within the canopy need to be quantified in order to link up different layers distributed vertically in the system, which all contribute to the net canopy/atmosphere exchange flux as measured by micrometeorology. Thus $\mathrm{NH}_{3}$ emissions by sources in soil or in the leaf litter at the soil surface, and by open stomata, may be partly recaptured by wet foliage. Personne et al. (2009) also argue that failing to account for the vertical temperature gradient within a canopy induces errors in the compensation point, since the relationship of $\chi_{s}$ to temperature is exponential, and they thus recommend the coupling of energy, water vapour and $\mathrm{NH}_{3}$ exchange modules. Double- or multiple-layer models are useful tools to further process understanding, but the increase in complexity, in the number of parameters needing to be fitted to measurements, and the temporal and spatial variations in source strength of the different layers, have so far hindered their implementation in regional-scale atmospheric models.

In this paper the bi-directional exchange of $\mathrm{NH}_{3}$ was modelled using a single-layer $\left(\chi_{s}-R_{w}\right)$ model for conditions outside slurry applications. A two-layer model was not applied due to the lack of detailed investigations of the soil, leaf litter and apoplastic emission potentials, i.e. $\Gamma$ values measured by extraction, which would be required to simulate fluxes within the canopy (Personne et al., 2009; Mattsson et al., 2009; Burkhardt et al., 2009; Nemitz et al., 2001; Mannheim et al., 1997). Inferences from micrometeorological measurements made above the canopy, as in the present case, could only deliver bulk canopy potentials $\left(\Gamma_{s}\right)$ and resistances $\left(R_{S}\right.$, $R_{w}$ ), which are consistent with, and directly applicable in, single-layer models. No straightforward interpretations of the same data could be made in relation to the distribution of sources and sinks in different layers, even though a detailed mechanistic understanding of all exchange processes is scientifically desirable (Nemitz et al., 2001).
Model performance was best when the canopy was short $(<20 \mathrm{~cm})$ and rather sparse, such as during the summer of 2006 (Fig. 9, left), and when the exchange was depositiondominated. In spring 2007 (Fig. 9, right), however, the canopy was taller (up to $35 \mathrm{~cm}$ ) and thicker, and the flux was clearly bi-directional. During the first $10 \mathrm{~d}$ (7-17 May 2007) and the last week (27 May-4 June 2007) of the time series shown, the single-layer model performs rather well, simulating the measured day-time emission and night-time uptake, but the agreement is less favourable in the interval 18-26 May 2007. Here, average ambient temperature was higher, leading to higher modelled emissions, which were not systematically confirmed by the measurements. Figure 9 (bottom frames) also shows the markedly different patterns in atmospheric $\mathrm{NH}_{3}$ concentrations between 2006 and 2007, with the generally higher ambient levels in 2006 leading to frequent deposition, and the lower levels in 2007 triggering more emissions. Overall, model performance was rather good as the grass canopy was generally very short $(70 \%$ of the time $<15 \mathrm{~cm} ; 81 \%$ of the time $<20 \mathrm{~cm} ; 86 \%$ of the time $<25 \mathrm{~cm}$, between 1 July 2006 and 31 October 2007).

The observed reduction over time in the $\mathrm{NH}_{3}$ source strength after slurry application (Fig. 2b, c) is a consequence of the $\mathrm{NH}_{4}^{+}$pool decreasing due to both $\mathrm{NH}_{3}$ volatilisation and absorption by the soil. As the application of manure systematically occurred shortly after grass cuts, the canopy was always very short $(<10 \mathrm{~cm})$ and open during the first few days of slurry emission events. Thus the canopy may be treated as a single-layer for the purpose of gap-filling, with the proposed procedure (Spirig et al., 2010) based on a semiempirical, semi-mechanistic approach involving the interpolated $\Gamma_{\text {slurry }}$ ratio.

\subsubsection{Non-stomatal $\mathrm{NH}_{3} \operatorname{sink}$}

The parameterisation of $R_{w}$ proposed in Eq. (14) and Fig. 4 corroborates the well-documented influence of leaf wetness via a surrogate in relative humidity (Sutton et al., 1998; Smith et al., 2000; Simpson et al., 2003) or in vapour pressure deficit (vpd) (Nemitz et al., 2000). Other models also use an RH-dependent non-stomatal resistance for water soluble trace gases like $\mathrm{SO}_{2}$ (Erisman et al., 1994; Zhang et al., 2003). However, the temperature control of $R_{w}$ has not gained much attention, and is rarely included in parameterisations (Smith et al., 2000; Simpson et al., 2003), except in the case of frozen surfaces, where $R_{w}$ increases as $T$ decreases below $\mathrm{O}^{\circ} \mathrm{C}$ (Wesely, 1989; Erisman et al. 1994; Zhang et al., 2003). Above freezing, temperature exerts a major forcing on trace gas solubility (Henry's law), dissociation in water, and heterogeneous reaction rates (Seinfeld and Pandis, 2006), which all control surface uptake rates (Flechard et al., 1999; Flechard and Fowler, 2008). The influence of temperature has often been overshadowed by that of $\mathrm{RH}$, as the two variables tend to be anti-correlated on a dailyand annual basis in Europe, but the Oensingen data do show 


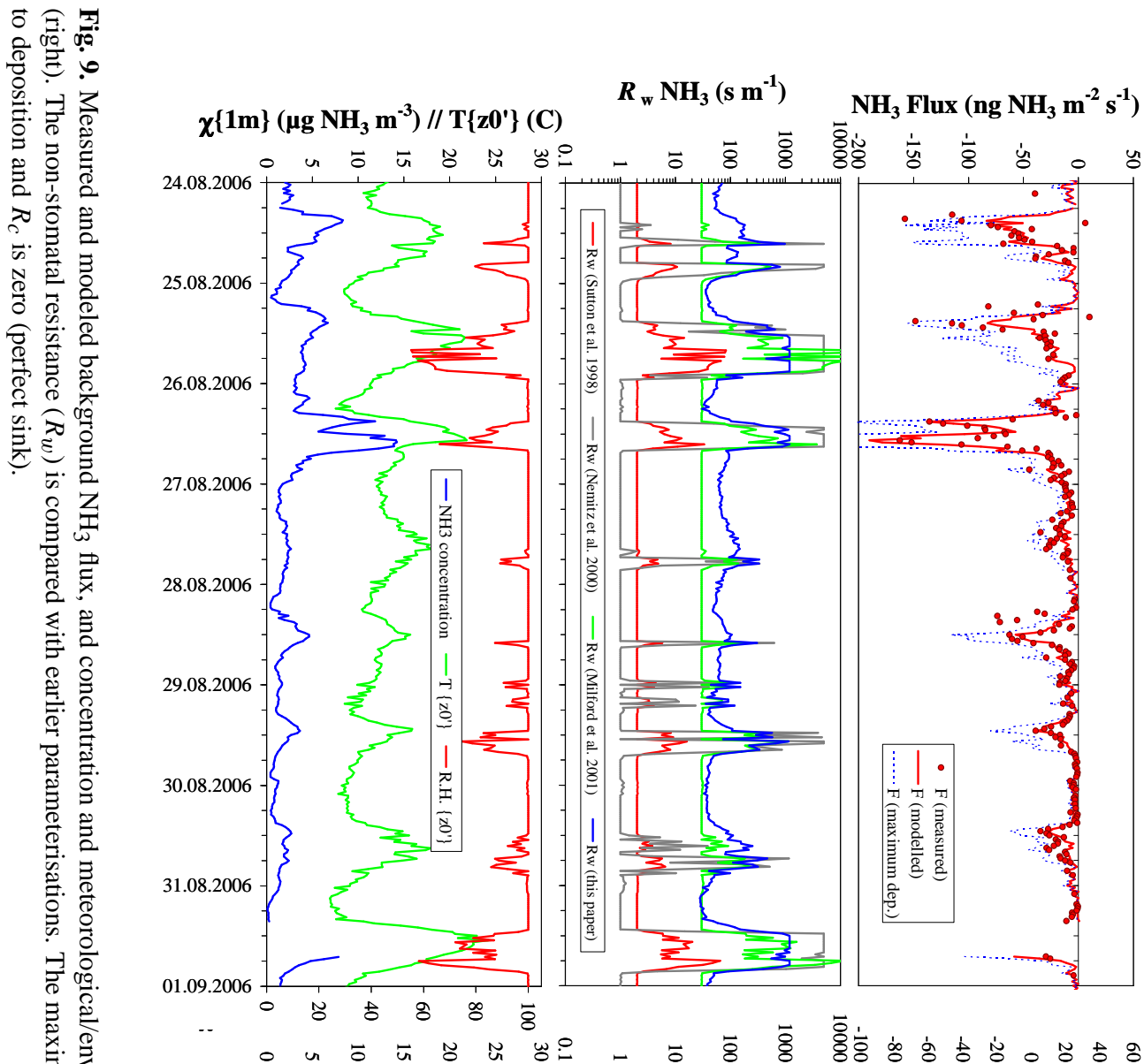

$$
R_{\mathrm{w}} \mathrm{NH}_{3}\left(\mathrm{~s} \mathrm{~m}^{-1}\right) \quad \mathrm{NH}_{3} \text { Flux }\left(\mathrm{ng} \mathrm{NH}_{3} \mathrm{~m}^{-2} \mathrm{~s}^{-1}\right)
$$

彥

จิ จำ

을.

응.

蛋

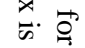

है

$\sum_{2}$

蛋

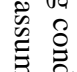

宊

要

$\stackrel{F}{=}$

芌桼

递

ค. 응

表

产

$\stackrel{\circ}{\circ}$

‥

F

总景.

통 용

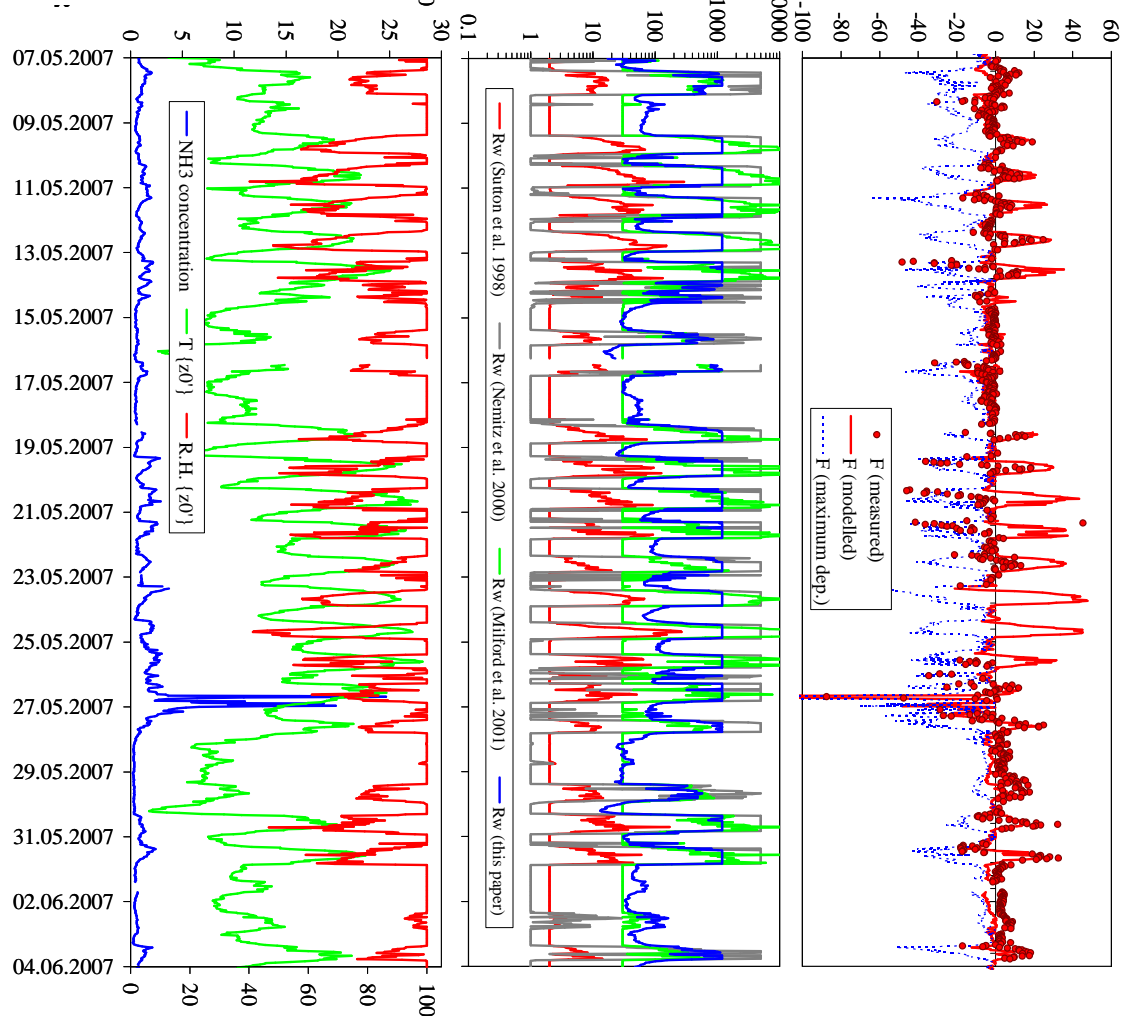

R.H. $\left\{z_{0}{ }^{\prime}\right\}(\%)$ 
unequivocally the temperature influence for each class of $\mathrm{RH}$ (Fig. 4). The exponential temperature factor accounts for the decreased effective solubility of $\mathrm{NH}_{3}$ (increased $R_{w}$ ) at higher temperatures, even when $\mathrm{RH}=100 \%$ and a water film is present. In the parameterisation by Smith et al. (2000) and Simpson et al. (2003), the temperature effect is logarithmic, so that $R_{w}$ at $20^{\circ} \mathrm{C}$, is only $24 \%$ higher than at $10^{\circ} \mathrm{C}$, while with Eq. (14) there is a factor $4.5(350 \%)$ increase in $R_{w}$ between $10^{\circ} \mathrm{C}$ and $20^{\circ} \mathrm{C}$. An exponential, rather than logarithmic, function of $R_{w}$ vs. $T$ is supported by the thermodynamic laws of $\mathrm{NH}_{3}$ solubility and dissociation (Seinfeld and Pandis, 2006).

Beside the temperature effect, measured and parameterised $R_{w}$ at Oensingen were much higher than values from earlier parameterisations by e.g. Sutton et al. (1998) and Nemitz et al. (2000), though consistent with the scheme by Milford et al. (2001b), adopted in the models of Riedo et al. (2002) and Personne et al. (2009) (Fig. 9). A number of factors may account for differences in $R_{w}$ parameterisations derived from different sites. Nemitz et al. (2001) argue that varying pollution climates across Europe lead to differences in surface uptake resistances, with the atmospheric molar ratio of $\mathrm{SO}_{2} / \mathrm{NH}_{3}$ acting as a scaling factor for $R_{w}$. They show that the most acidic surfaces (highest $\mathrm{SO}_{2} / \mathrm{NH}_{3}$ ratio, $>0.8 \mathrm{ppb} \mathrm{ppb}^{-1}$ ) in the English Midlands have the lowest $R_{w}$ for $\mathrm{NH}_{3}$, while areas of intensive agriculture in Southern England and in The Netherlands (lowest $\mathrm{NH}_{3} / \mathrm{SO}_{2}$ ratio, $<0.2 \mathrm{ppb} \mathrm{ppb}^{-1}$ ) have the highest non-stomatal resistance. A similar argument was developed by Fowler et al. (2001) regarding the control by $\mathrm{NH}_{3}$ of the canopy resistance for $\mathrm{SO}_{2}$. In a recent $\mathrm{NH}_{3}$ fumigation study over moorland, Jones et al. (2007) showed a concentration-dependent cuticular resistance for $\mathrm{NH}_{3}$, although the range of concentrations (10-100 $\left.\mu \mathrm{g} \mathrm{m}^{-3}\right)$, in which they derived the relationship, was much higher than ambient concentrations normally encountered in the countryside, except in the near vicinity of animal housing (Walker et al., 2008).

At Oensingen the geometric mean $\mathrm{SO}_{2}$ concentration is around $1 \mathrm{ppb}$, based on data from the nearby Härkingen station of the Swiss National Air Pollution Monitoring Network (NABEL) (http://www.bafu.admin.ch/luft/luftbelastung/ blick_zurueck/datenabfrage/index.html?lang=en). The geometric mean $\mathrm{NH}_{3}$ concentration around $4-5 \mathrm{ppb}$, so the mean $\mathrm{SO}_{2} / \mathrm{NH}_{3}$ molar ratio is low, of the order of $0.2-0.25$. For comparison with the review by Nemitz et al. (2001), at $\mathrm{RH}=95 \%$ and $T=10^{\circ} \mathrm{C}$, Eq. (14) yields an $R_{w}$ of $78 \mathrm{~s} \mathrm{~m}^{-1}$, which is the highest of all values in that compilation, but thoroughly in agreement with the argument by Nemitz et al. that $\mathrm{NH}_{3}$-dominated atmospheres like Oensingen and the Swiss Plateau likely lead to elevated $R_{w}$ values. This study therefore strongly supports the case for the implementation of the $\mathrm{SO}_{2} / \mathrm{NH}_{3}$ (or total acids $/ \mathrm{NH}_{3}$ ) ratio in $R_{w}$ parameterisations in regional-scale atmospheric models, as recently adopted in the EMEP scheme (Simpson et al., 2003).
In the single-layer $\chi_{c}$ model, the $R_{w}$ term describes not only leaf surface cuticular exchange, but also all other nonstomatal processes occurring in parallel. Similarly, when a bulk $R_{w}$ is experimentally derived from night-time flux measurements, its variations are controlled not only by the wetness, temperature and chemistry of leaf surfaces (Sutton et al., 1998; Flechard et al., 1999), but also by soil and litter exchange. Thus $\mathrm{NH}_{3}$ emissions by ground level (soil or litter) sources, when they occur, would in effect raise the observed value of $R_{w}$, provided that the net exchange flux above the canopy is still downward and an $R_{w}$ can be calculated. The magnitude of this effect is difficult to assess for the Oensingen data, as no complementary measurements of the soil or litter emission potential were made, but the comparability with previous studies (Milford et al., 2001; Nemitz et al., 2001) supports the validity of our $R_{w}$ estimates. On the other hand, if this parameterisation is to be implemented in a single-layer model of $\mathrm{NH}_{3}$ exchange, which therefore does not account for ground level emissions, then it could be argued that $R_{w}$ should in some way reflect the reduction in the net (bulk) sink capacity of the canopy induced by minor, non-stomatal emission processes. Thus, in theory, $R_{w}$ parameterisations used in single-layer models ought to differ from those used in double-layer models, as the range of canopy processes encompassed is not identical.

The large scatter in the data of Fig. 4 reflects the uncertainties associated with a parameterisation that seeks to explain observed variations in $R_{w}$ with only two variables, $T$ and $\mathrm{RH}$, which in addition cannot be considered to be independent of each other. Indeed, on annual and daily bases they are largely inversely correlated, so that the full matrix of $T$ vs. RH in the environmental range cannot be fully described. Further, data selection (night-time only) ensures that few data are available for the lower end of the RH range, with most data clustered near 100\% RH. Thus the symbols in Fig. 4, representing mean $R_{w}$ values within classes of $T$ and $\mathrm{RH}$, do not possess equal weight, although this was accounted for in the determination of the overall fit. Much additional scatter is expected to be caused by variations in the sink- and source strengths as disscussed above $\left(\mathrm{SO}_{2}\right.$, rainfall and leaf surface chemistry, histeresis, leaf litter, soil wetness), which result in an overall coefficient of determination (R2) of the parameterised (fitted) vs. measured Rw data (Fig. 4) of 0.08 .

\subsection{Contribution of managed grasslands to national emissions}

The annual net $\mathrm{NH}_{3}$ budget of $+17 \mathrm{~kg} \mathrm{NH}_{3}-\mathrm{Nha}^{-1} \mathrm{yr}^{-1}$ is higher than those presented for managed grasslands by Plantaz (1998) with an annual net emission of $+3.7 \mathrm{~kg}$ $\mathrm{NH}_{3}-\mathrm{N} \mathrm{ha}^{-1} \mathrm{yr}^{-1}$ at Zegveld (NL), and by Milford (2004) with an annual net emission of $+1.9 \mathrm{~kg} \mathrm{NH}_{3}-\mathrm{N} \mathrm{ha}^{-1} \mathrm{yr}^{-1}$ at Easter Bush (UK), and lower than at Schagerbrug (NL) with $+26 \mathrm{~kg} \mathrm{NH}_{3}-\mathrm{N} \mathrm{ha}^{-1} \mathrm{yr}^{-1}$ (Mosquera et al., 2001). Comparisons between sites are difficult because of differences in 
management, livestock density, fertilisation rates, climate, soil type and grassland composition. Zegveld and Easter Bush were both grazed and fertilised systems, in which net emission occurred during the grazing season and net deposition occurs during the rest of the year, while Oensingen and Schagerbrug are both fertilised, cut (ungrazed) grasslands, in which 4 to 5 manure or fertiliser applications per year trigger sharp emission peaks. Grassland management in 2006-2007 at Oensingen, with 4 successive applications of liquid cattle manure between July 2006 and June 2007, was somewhat atypical for the Swiss Plateau and slightly different from the normal practices at this site, which had received in each calendar year since 2002, 2-3 applications of cattle slurry and 2 applications of mineral $\left(\mathrm{NH}_{4} \mathrm{NO}_{3}\right)$ fertiliser (Flechard et al., 2005). Although the cumulated annual fertilisation rate was similar, of the order of $200 \mathrm{~kg} \mathrm{~N} \mathrm{ha}^{-1} \mathrm{yr}^{-1}$, it might be expected that the annual $\mathrm{NH}_{3}$ emission was higher than would have been if synthetic fertiliser had been used intermittently.

In Switzerland, agriculture contributes $93 \%$ of total national $\mathrm{NH}_{3}$ emissions (44.6 kt $\mathrm{NH}_{3}-\mathrm{N}$ in 2000), with livestock production and manure management accounting for $88 \%$ of agricultural emissions (Reidy et al., 2008). The same inventory estimates manure and slurry spreading to contribute $58 \%$ of total emissions, i.e. $26 \mathrm{kt} \mathrm{NH}_{3}-\mathrm{N}$, vs. $28 \%$ by animal houses and hardstanding, $12 \%$ by manure storage, and $2 \%$ by grazing. The proportion of cow manure managed as slurry increased from $30 \%$ in 1990 to $50 \%$ in 2002 , while over $80 \%$ of the slurry was applied onto grassland. These figures show the greater sensitivity of the Swiss national emission estimates to the emission factors used for slurry applied to grasslands, compared with other European countries, where the share of applied manure emissions is much less, of the order of 35\% of total emissions (Misselbrook et al., 2000).

The total Swiss agricultural surface area is $1.5 \mathrm{Mha}$, of which around $80 \%$ is grassland, i.e. $1.2 \mathrm{Mha}$ or $12000 \mathrm{~km}^{2}$ (Swiss Federal Statistical Office; http://www.bfs.admin.ch/ bfs/portal/en/index.html). If one considers in a first approximation the gross annual emission budget of $+20 \mathrm{~kg} \mathrm{NH}_{3}$ $\mathrm{Nha}^{-1} \mathrm{yr}^{-1}$ measured at Oensingen to be representative of all Swiss agricultural surfaces, the upscaled national estimate of emissions by land-applied animal manures and slurries would be $30.5 \mathrm{kt} \mathrm{NH}_{3}-\mathrm{N} \mathrm{yr}^{-1}$, comparable with the estimate of $26 \mathrm{kt} \mathrm{NH}_{3}-\mathrm{N} \mathrm{yr}^{-1}$ by Reidy et al. (2008). However, taking into account the higher annual manure input during this study (4 applications per year), compared with standard practice at this site and across Switzerland (2-3 applications per year), then the upscaled gross emission should be between $25 \%$ and $50 \%$ lower, i.e. of the order of $15-23 \mathrm{kt} \mathrm{NH}_{3}-\mathrm{N} \mathrm{yr}^{-1}$. In a similar exercise for the UK, Milford (2004) scaled up the Easter Bush gross emission of $4.2 \mathrm{~kg} \mathrm{~N} \mathrm{ha}^{-1} \mathrm{yr}^{-1}$ across the whole of the UK improved grassland $\left(60500 \mathrm{~km}^{2}\right)$, leading to $25 \mathrm{ktNH}_{3}-\mathrm{N} \mathrm{yr}^{-1}$, equivalent to $9.5 \%$ of the UK total emissions. Such upscaling is necessarily speculative and does not account for the variability in vegetation, soil types and manure types, but it still shows that much uncertainty remains and more experimental evidence should be gathered. Further, the validity of emission factors used for field-applied cattle slurry needs to be questioned (Spirig et al., 2010).

National and regional atmospheric models cannot currently treat ammonia emissions from applied manures and slurries dynamically, due to computational limits and to lack of input data for farming practices and manure type and/or composition. Models often do not feature bi-directional background exchange either. Typically, gross $\mathrm{NH}_{3}$ emissions are provided by emission factors/inventories and $\mathrm{NH}_{3}$ is generally dry-deposited only (Sutton et al., 1995b; Simpson et al., 2003; Zhang et al., 2003). In the Lagrangian Fine Resolution AMmonia Exchange (FRAME) model developed for the UK by Singles et al. (1998), the emission inventory used to derive the national $\mathrm{NH}_{3}$ concentration map treats grazed grasslands as a net source, with a large $R_{c}$ implemented so that dry deposition to grazed grasslands is negligible. Smith et al. (2000) used the $\mathrm{NH}_{3}$ concentration field derived from FRAME and applied a compensation point approach for crops and cut grasslands, though not to grazed grasslands to avoid circularity. This heterogeneity of modeling approaches used at the national/regional scales, and the often artificial split made between source and sink areas, both highlight the need for more mechanistic approaches involving process-based emissions inventories, as $\mathrm{NH}_{3}$ emitters and receptors can co-occur over time and space in rural landscapes.

\section{Conclusions}

Semi-continuous micrometeorological measurements of $\mathrm{NH}_{3}$ exchange fluxes above intensively managed grassland and over several seasons were analysed to provide an estimate of the annual $\mathrm{NH}_{3}$ budget, which was very sensitive to the approach used for time integration of fluxes. The fertilised, cut grassland in this study was a net $\mathrm{NH}_{3}$ source over a period of one year, though only because cattle slurry was applied several times. During periods of background exchange grassland was mostly a net sink despite small daytime emissions in spring and summer conditions. The direction and magnitude of background $\mathrm{NH}_{3}$ fluxes were controlled in part by the ambient $\mathrm{NH}_{3}$ concentration, with a clear difference between 2006 and 2007, demonstrating the need for a stomatal- and canopy compensation point modeling approach. Ammonia emissions from applied slurry were controlled by the exponential decline over time of an evaporating initial $\mathrm{NH}_{3} / \mathrm{NH}_{4}^{+}$pool in deposited slurry patches and by the penetration of $\mathrm{NH}_{4}^{+}$into the soil-root system. The measurements did not provide any clear experimental evidence that slurry applications lead to a long-term enhancement of the $\mathrm{NH}_{3}$ emission potential in grassland, beyond the immediate effect of the short-term release of ammoniacal $\mathrm{N}$ deposited 


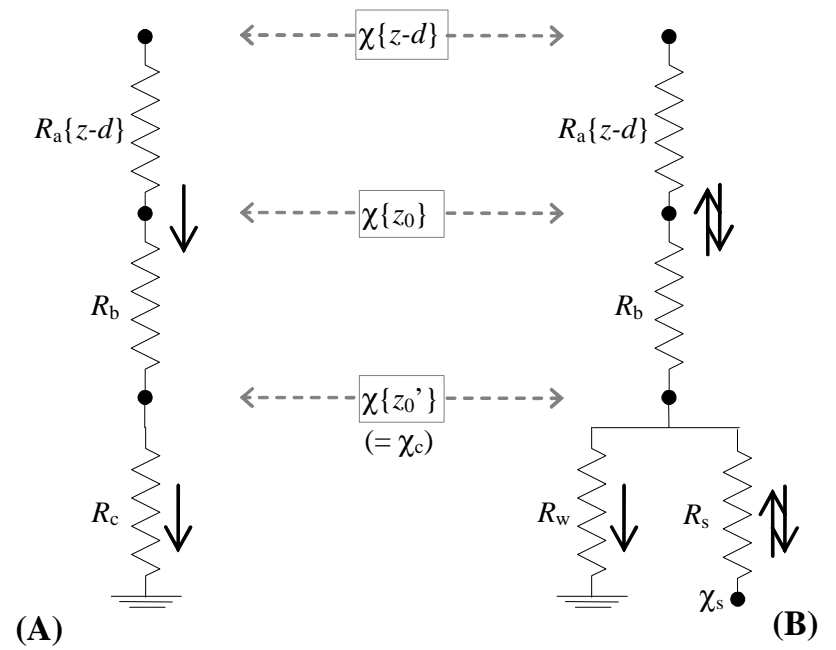

Fig. A1. Schematic representations of (A) the canopy resistance $R_{C}$ model, and (B) the one-layer canopy compensation point $\chi_{s}-R_{w}$ model by Sutton et al. (1998).

in slurry. The extent to which fertilisation raises the stomatal compensation point of a plant community thus needs to be further investigated. Our analysis of background vs. events has sought to distinguish plant (internal) physiological exchange processes from the fertilisation-induced disturbance of plant/soil surface (external) chemistry, in order to treat $\mathrm{NH}_{3}$ exchange in regional models assuming near steady-state for the stomatal $\Gamma_{s}$.

Long-term (viz annual or longer) monitoring datasets of both background exchange and fertilisation-induced emissions are scarce in grasslands and other agro-ecosystems. This study adds new estimates of $\Gamma_{s}, R_{w}$ and of the annual $\mathrm{NH}_{3}$ budget to the existing grassland literature, but spatial and temporal variations in compensation points at the landscape and regional scales need to be better quantified in relation to differences in long-term fertilisation status and atmospheric $\mathrm{N}$ deposition. Likewise the link of $R_{w}$ to the local pollution climate requires more validation data. More field-scale micrometeorological measurements are especially needed for fluxes following slurry application, to compare with plot-scale, wind tunnel and chamber data, which form the core of published emission factors and national inventories.

\section{Appendix A}

See Fig. A1.
Acknowledgements. This work was carried out as part of the European Union 6th Framework Projects NitroEurope IP (Contract FP6-GOCE 017841) and CarboEurope IP (Contract FP6-GOCECT-2003-505572). We are grateful to M. Sutton of CEH Edinburgh for his comments on the manuscript, and to W. Ingold at the Oensingen farm for his long-standing and friendly cooperation on the field.

Edited by: F. X. Meixner

\section{References}

Amann, M., Bertok, I., Cofala, J., Gyarfas, F., Heyes, C., Klimont, Z., Schöpp,W., and Winiwarter, W.: Baseline Scenarios for the Clean Air for Europe (CAFE) Programme, Final Report, Contract No B4-3040/2002/340248/MAR/C1, IIASA, Laxenburg, Austria, 2005.

Ammann, C., Flechard, C. R., Leifeld, J., Neftel, A., and Fuhrer, J.: The carbon budget of newly established temperate grassland depends on management intensity, Agric. Ecosyst. Environ., 121, 5-20, 2007.

Ammann, C., Spirig, C., Leifeld, J., and Neftel, A.: Assessment of the nitrogen and carbon budget of two managed temperate grassland fields, Agric. Ecosyst. Environ., 133, 150-162, 2009.

Baldocchi, D. D., Hicks, B. B., and Camara, P.: A canopy stomatal resistance model for gaseous deposition to vegetated surfaces, Atmos. Environ., 21, 91-101, 1987.

Burkhardt, J., Flechard, C. R., Gresens, F., Mattsson, M., Jongejan, P. A. C., Erisman, J. W., Weidinger, T., Meszaros, R., Nemitz, E., and Sutton, M. A.: Modelling the dynamic chemical interactions of atmospheric ammonia with leaf surface wetness in a managed grassland canopy, Biogeosciences, 6, 67-83, 2009, http://www.biogeosciences.net/6/67/2009/.

Bussink, D. W., Harper, L., and Corré, W. J.: Ammonia transport in a temperate grassland: II. Diurnal fluctuations in response to weather and management conditions, Agron. J., 88, 621-626, 1996.

Dabney, S. M. and Bouldin, D. R.: Apparent deposition velocity and compensation point of ammonia inferred from gradient measurements above and through alfalfa, Atmos. Environ., 24A, 26552666, 1990.

Erisman, J. W., van Pul, A., and Wyers, P.: Parametrization of surface resistance for the quantification of atmospheric deposition of acidifying pollutants and ozone, Atmos. Environ., 28, 25952607, 1994.

Erisman, J. W., Otjes, R., Hensen, A., Jongejan, P., van den Bulk, P., Khlystov, A., Möls, H., and Slanina, S.: Instrument development and application in studies and monitoring of ambient ammonia, Atmos. Environ., 35, 1913-1922, 2001.

Erisman, J. W., Bleeker, A., Galloway, J., and Sutton, M. A.: Reduced nitrogen in ecology and the environment, Environ. Pollut., 150, 140-149, 2007.

Farquhar, G. D., Firth, P. M., Wetselaar, R., and Weir, B.: On the gaseous exchange of ammonia between leaves and the environment: determination of the ammonia compensation point, Plant Physiol., 66, 710-714, 1980.

Ferm, M., Method for determination of atmospheric ammonia, Atmos. Environ., 13, 1385-1393, 1979.

Flechard, C. R. and Fowler, D.: Atmospheric ammonia at a moorland site. II: Long term surface/atmosphere micrometeorological 
flux measurements, Q. J. Roy. Meteor. Soc., 124, 759-791, 1998.

Flechard, C. R., Fowler, D., Sutton, M. A., and Cape, J. N.: A dynamic chemical model of bi-directional ammonia exchange between semi-natural vegetation and the atmosphere, Q. J. Roy. Meteor. Soc., 125, 2611-2641, 1999.

Flechard, C. R., Neftel, A., Jocher, M., Ammann, C., and Fuhrer, J.: Bidirectional soil-atmosphere $\mathrm{N}_{2} \mathrm{O}$ exchange over two mown grassland systems with contrasting management practices, Glob. Change Biol., 11, 2114-2127, 2005.

Flechard, C. R. and Fowler, D.: Effects of Changing Temperature on Leaf Surface Water-Film Chemistry and Trace Gas Exchange Processes over Terrestrial Vegetation, in: The Impact of Climate Change on Air Quality. The 4th ACCENT Barnsdale Expert Workshop, edited by: Builtjes, P., Fowler, D., Feichter, J., Lewis, A., Monks, P., and Borrell, P., ACCENT Secretariat, Urbino, March 2008, 155-161, 2008.

Fowler, D., Sutton, M. A., Flechard, C. R., Cape, J. N., StoretonWest, R. S., Coyle, M., and Smith, R. I.: The control of $\mathrm{SO}_{2}$ dry deposition on to natural surfaces and its effects on regional deposition, Water Air Soil Pollut. Focus, 1, 39-48, 2001.

Galloway, J. N., Aber, J. D., Erisman, J. W., Seitzinger, S. P., Howarth, R. W., Cowling, E. B., and Cosby, B. J.: The nitrogen cascade, Bioscience, 53, 341-356, 2003.

Garland, J. A.: The dry deposition of sulphur dioxide to land and water surfaces, Proc. R. Soc. Lond. A, 354, 245-268, 1977.

Génermont, S. and Cellier, P.: A mechanistic model for estimating ammonia volatilization from slurry applied to bare soil, Agr. Forest Meteorol., 88, 145-167, 1997.

Génermont, S., Cellier, P., Flura, P., Morvan, T., and Laville, P.: Measuring ammonia fluxes after slurry spreading under actual field conditions, Atmos. Environ., 32, 279-284, 1998.

Harper, L. A., Denmead, O. T., and Sharpe, R. R.: Identifying sources and sinks of scalars in a corn canopy with inverse Lagrangian dispersion analysis 2. Ammonia, Agr. Forest Meteorol., 104, 75-83, 2000.

Herrmann, B., Jones, S. K., Fuhrer, J., Feller, U., and Neftel, A.: N budget and $\mathrm{NH}_{3}$ exchange of a grass/clover crop at two levels of $\mathrm{N}$ application, Plant Soil, 235, 243-252, 2001.

Herrmann, B., Mattsson, M., Jones, S. K., Cellier, P., Milford, C., Sutton, M. A., Schjoerring, J. K., and Neftel, A.: Vertical structure and diurnal variability of ammonia exchange potential within an intensively managed grass canopy, Biogeosciences, 6 , 15-23, 2009,

http://www.biogeosciences.net/6/15/2009/.

Hesterberg, R., Blatter, A., Fahrni, M., Rosset, M., Neftel, A., Eugster, W., and Wanner, H.: Deposition of nitrogen-containing compounds to an extensively managed grassland in central Switzerland, Environ. Pollut., 91, 1-34, 1996.

Hicks, B. B., Baldocchi, D. D., Meyers, T. P., Hosker Jr., R. P., and Matt, D. R.: A preliminary multiple resistance routine for deriving dry deposition velocities from measured quantities, Water Air Soil Pollut., 36, 311-330, 1987.

Horváth, L., Asztalos, M., Führer, E., Mészáros, R., and Weidinger, T.: Measurement of ammonia exchange over grassland in the Hungarian Great Plain, Agr. Forest Meteorol., 130, 282-298, 2005.

Jarvis, P. G.: The interpretation of the variations in leaf water potential and stomatal conductance found in canopies in the field, Philos. T. Roy. Soc. London B, 273, 593-610, 1976.
Jones, M. R., Leith, I. D., Fowler, D., Raven, J. A., Sutton, M. A., Nemitz, E., Cape, J. N., Sheppard, L. J., Smith, R. I., and Theobald, M. R.: Concentration-dependent $\mathrm{NH}_{3}$ deposition processes for mixed moorland semi-natural vegetation, Atmos. Environ., 41, 2049-2060, 2007.

Kormann, R. and Meixner, F. X.: An analytical footprint model for non-neutral stratification, Bound. Lay. Meteorol., 99, 207-224, 2001.

Loubet, B., Milford, C., Sutton, M. A., and Cellier, P.: Investigation of the interaction between sources and sinks of atmospheric ammonia in an upland landscape using a simplified dispersionexchange model, J. Geophys. Res., 106(D20), 24183-24195, 2001.

Loubet, B., Milford, C., Hill, P. W., Tang, Y. S., Cellier, P., and Sutton, M. A.: Seasonal variability of apoplastic $\mathrm{NH}_{4}^{+}$and $\mathrm{pH}$ in an intensively managed grassland, Plant Soil, 238, 97-110, 2002.

Mannheim, T., Braschkat, J., and Marschner, H.: Ammonia emissions from senescing plants and during decompostion of crop residues, Z. Pflanz. Bodenkunde, 160, 125-132, 1997.

Massad, R. S., Loubet, B., Tuzet, A., and Cellier, P.: Relationship between ammonia stomatal compensation point and nitrogen metabolism in arable crops: Current status of knowledge and potential modeling approaches, Environ. Pollut., 154, 390-403, 2008.

Mattsson, M., Herrmann, B., David, M., Loubet, B., Riedo, M., Theobald, M. R., Sutton, M. A., Bruhn, D., Neftel, A., and Schjoerring, J. K.: Temporal variability in bioassays of the stomatal ammonia compensation point in relation to plant and soil nitrogen parameters in intensively managed grassland, Biogeosciences, 6, 171-179, 2009,

http://www.biogeosciences.net/6/171/2009/.

Mattsson, M. and Schjoerring, J. K.: Dynamic and steady-state responses of inorganic nitrogen pools and $\mathrm{NH}_{3}$ exchange in leaves of lolium perenne and bromus erectus to changes in root nitrogen supply, Plant Physiol., 128, 742-750, 2002.

Milford, C.: Dynamics of atmospheric ammonia exchange with intensively-managed grassland, Ph.D. Thesis, University of Edinburgh, UK, 218 pp., 2004.

Milford, C., Hargreaves, K. J., Sutton, M. A., Loubet, B., and Cellier, P.: Fluxes of $\mathrm{NH}_{3}$ and $\mathrm{CO}_{2}$ over upland moorland in the vicinity of agricultural land, J. Geophys. Res., 106, 2416924181, 2001a.

Milford, C., Theobald, M. R., Nemitz, E., and Sutton M. A.: Dynamics of ammonia exchange in response to cutting and fertilizing in an intensively-managed grassland, Water Air Soil Pollut. Focus, 1, 167-176, 2001b.

Misselbrook, T. H., van der Weerden, T. J., Pain, B. F., Jarvis, S. C., Chambers, B. J., Smith, K. A., Phillips, V. R., and Demmers, T. G. M.: Ammonia emission factors for UK agriculture, Atmos. Environ., 34, 871-880, 2000.

Monteith, J. L. and Unsworth, M. H.: Principles of Environmental Physics, 2nd edition, Edward Arnold, London, 1990.

Mosquera, J., Hensen, A., van den Bulk, W. C. M., Vermeulen, A. T., and Erisman, J. W.: Long Term $\mathrm{NH}_{3}$ Flux Measurements Above Grasslands in The Netherlands: Comparison between an Intensive and an Extensive Field, Water Air Soil Pollut. Focus, 1, 203-212, 2001.

Neftel, A., Spirig, C., and Ammann, C.: Application and test of a simple tool for operational footprint evaluations, Environ. Pol- 
lut., 152, 644-652, 2008.

Nemitz, E., Milford, C., and Sutton, M. A.: A two-layer canopy compensation point model for describing bi-directional biosphere-atmosphere exchange of ammonia, Q. J. Roy. Meteor. Soc., 127, 815-833, 2001.

Nemitz, E., Sutton, M. A., Schjoerring, J. K., Husted, S., and Wyers, G. P.: Resistance modeling of ammonia exchange over oilseed rape, Agr. Forest Meteorol., 105, 405-425, 2000.

Personne, E., Loubet, B., Herrmann, B., Mattsson, M., Schjoerring, J. K., Nemitz, E., Sutton, M. A., and Cellier, P.: SURFATMNH3: a model combining the surface energy balance and bidirectional exchanges of ammonia applied at the field scale, Biogeosciences, 6, 1371-1388, 2009,

http://www.biogeosciences.net/6/1371/2009/.

Pitcairn, C. E. R., Leith, I. D., Sheppard, L. J., Sutton, M. A., Fowler, D., Munro, R. C., Tang, S., and Wilson, D.: The relationship between nitrogen deposition, species composition and foliar nitrogen concentrations in woodland flora in the vicinity of livestock farms, Environ. Pollut., 102, 41-48, 1998.

Plantaz, M. A. H. G.: Surface/atmosphere exchange of ammonia over grazed pasture, Ph.D. Thesis, Agricultural University of Wageningen, The Netherlands, 199 pp., 1998.

Reidy, B., Rhim, B., and Menzi, H.: A new Swiss inventory of ammonia emissions from agriculture based on a survey on farm and manure management and farm-specific model calculations, Atmos. Environ., 42, 3266-3276, 2008.

Riedo, M., Milford, C., Schmid, M., and Sutton, M. A.: Coupling soil-plant-atmosphere exchange of ammonia with ecosystem functioning in grasslands, Ecol. Model., 158, 83-110, 2002.

Seinfeld, J. H. and Pandis, S. N.: Atmospheric chemistry and physics. From Air Pollution to climate Change, second edition, John Wiley and Sons, New Jersey, 2006.

Simpson, D., Fagerli, H., Jonson, J. E., Tsyro, S., Wind, P., and Tuovinen, J.-P.: Transboundary Acidification, Eutrophication and Ground Level Ozone in Europe. Part I: Unified EMEP Model Description, EMEP Status Report 2003, ISSN 0806-4520, Det Meteorologisk Institutt, Oslo, 2003.

Singles, R., Sutton, M. A., and Weston, K. J.: A multi-layer model to describe the atmospheric transport and deposition of ammonia in Great Britain, Atmos. Environ., 32, 393-399, 1998.

Smith, R. I., Fowler, D., Sutton, M. A., Flechard, C., and Coyle, M.: Regional estimation of pollutant gas deposition in the UK: model description, sensitivity analyses and outputs, Atmos. Environ., 34, 3757-3777, 2000.

Sorteberg, A. and Hov, Ø.: Two parametrizations of the dry deposition exchange for $\mathrm{SO}_{2}$ and $\mathrm{NH}_{3}$ in a numerical model, Atmos. Environ., 30, 1823-1840, 1996.

Spindler, G., Teichmann, U., and Sutton, M. A.: Ammonia dry deposition over grassland - micrometeorological flux-gradient measurements and bidirectional flux calculations using an inferential model, Q. J. Roy. Meteor. Soc., 127, 795-814, 2001.

Spirig, C., Flechard, C. R.,, and Ammann, C. Neftel, A.: The annual ammonia budget of fertilised cut grassland - Part 1: Micrometeorological flux measurements and emissions after slurry application, Biogeosciences, 7, 521-536, 2010, http://www.biogeosciences.net/7/521/2010/.

Sutton, M. A., Schjørring, J. K., and Wyers, G. P.: Plant-atmosphere exchange of ammonia, Philos. T. Roy. Soc. London A, 351, 261278, 1995a.
Sutton, M. A., Place, C. J., Eager, M., Fowler, D., and Smith, R. I.: Assessment of the magnitude of ammonia emissions in the United Kingdom, Atmos. Environ., 29, 1393-1411, 1995 b.

Sutton, M. A., Milford, C., Dragosits, U., Singles, R., Fowler, D., Ross, C., Hill, R., Jarvis, S. C., Pain, B. F., Harrison, R., Moss, D., Webb, J., Espenhahn, S., Halliwell, C., Lee, D. S., Wyers, G. P., Hill, J., and ApSimon, H. M.: Gradients of atmospheric ammonia concentrations and deposition downwind of ammonia emissions: first results of the ADEPT Burrington Moor experiment, in: Gaseous nitrogen emissions from grasslands, edited by: Jarvis, S. C. and Pain, B. F., Cab International, Wallingford, UK, 131-139, 1997.

Sutton M. A., Burkhardt J. K., Guerin D., Nemitz E., and Fowler D.: Development of resistance models to describe measurements of bi-directional ammonia surface atmosphere exchange, Atmos. Environ., 32(3), 473-480, 1998.

Sutton, M. A., Nemitz, E., Milford, C., Campbell, C., Erisman, J. W., Hensen, A., Cellier, P., David, M., Loubet, B., Personne, E., Schjoerring, J. K., Mattsson, M., Dorsey, J. R., Gallagher, M. W., Horvath, L., Weidinger, T., Meszaros, R., Dämmgen, U., Neftel, A., Herrmann, B., Lehman, B. E., Flechard, C., and Burkhardt, J.: Dynamics of ammonia exchange with cut grassland: synthesis of results and conclusions of the GRAMINAE Integrated Experiment, Biogeosciences, 6, 2907-2934, 2009,

http://www.biogeosciences.net/6/2907/2009/.

Sutton, M. A., Nemitz, E., Theobald, M. R., Milford, C., Dorsey, J. R., Gallagher, M. W., Hensen, A., Jongejan, P. A. C., Erisman, J. W., Mattsson, M., Schjoerring, J. K., Cellier, P., Loubet, B., Roche, R., Neftel, A., Hermann, B., Jones, S. K., Lehman, B. E., Horvath, L., Weidinger, T., Rajkai, K., Burkhardt, J., Löpmeier, F. J., and Daemmgen, U.: Dynamics of ammonia exchange with cut grassland: strategy and implementation of the GRAMINAE Integrated Experiment, Biogeosciences, 6, 309-331, 2009, http://www.biogeosciences.net/6/309/2009/.

Sutton M. A., Tang Y. S., Miners B., and Fowler, D.: A new diffusion denuder system for long term, regional monitoring of atmospheric ammonia and ammonium, Water Air Soil Pollut. Focus, 1, 145-156, 2001.

Sutton, M. A., Nemitz, E., Erisman, J. W., Beier, C., ButterbachBahl, K., Cellier, P., de Vries, W., Cotrufo, F., Skiba, U., Di Marco, C., Jones, S., Laville, P., Soussana, J. F., Loubet, B., Twigg, M., Famulari, D., Whitehead, J., Gallagher, M. W., Neftel, A., Flechard, C. R., Herrmann, B., Calanca, P. L., Schjoerring, J. K., Daemmgen, U., Horvath, L., Tang, Y. S., Emmett, B. A., Tietema, A., Peñuelas, J., Kesik, M., Brueggemann, N., Pilegaard, K., Vesala, T., Campbell, C. L., Olesen, J. E., Dragosits, U., Theobald, M. R., Levy, P., Mobbs, D. C., Milne, R., Viovy, N., Vuichard, N., Smith, J. U., Smith, P., Bergamaschi, P., Fowler, D., and Reis, S.: Challenges in quantifying biosphereatmosphere exchange of nitrogen species, Environ. Pollut., 150, 125-139, 2007.

Tang, Y. S., Simmons, I., van Dijk, N., Di Marco, C., Nemitz, E., Dämmgen, U., Gilke, K., Djuricic, V., Vidic, S., Gliha, Z., Borovecki, D., Mitosinkova, M., Hanssen, J. E., Uggerud, T. H., Sanz, M. J., Sanz, P., Chorda, J. V., Flechard, C. R., Fauvel, Y., Ferm, M., Perrino, C., and Sutton, M. A.: European scale application of atmospheric reactive nitrogen measurements in a lowcost approach to infer dry deposition fluxes, Agr. Ecosyst. Environ., 133, 183-195, 2009. 
Thom, A. S.: Momentum, mass and heat exchange of plant communities, in: Vegetation and the atmosphere, vol. 1, edited by: Monteith, J. L., Academic Press, London, 57-109, 1975.

Thompson, R. B. and Meisinger, J. J.: Gaseous nitrogen losses and ammonia volatilization measurement following land application of cattle slurry in the mid-Atlantic region of the USA, Plant Soil, 266, 231-246, 2004.

van Hove, L. W. A., Heeres, P., and Bossen, M. E.: The annual variation in stomatal ammonia compensation point of rye grass (Lolium perenne L.) leaves in an intensively managed grassland, Atmos. Environ., 36, 2965-2977, 2002.

Walker, J. T., Robarge, W. P., Wu, Y., and Meyers, T.: Measurement of bi-directional ammonia fluxes over soybean using the modified Bowen-ratio technique, Agr. Forest Meteorol., 138, 54-68, 2006.

Walker, J., Spence, P., Kimbrougha, S., and Robarge, W.: Inferential model estimates of ammonia dry deposition in the vicinity of a swine production facility, Atmos. Environ., 42, 3407-3418, 2008.
Wesely, M. L.: Parameterisation of surface resistances to gaseous dry deposition in regional-scale numerical models, Atmos. Environ., 23, 1293-1304, 1989.

Wichink Kruit, R. J., van Pul, W. A. J., Otjes, R. P., Hofschreuder, P., Jacobs, A. F. G., and Holtslag, A. A. M.: Ammonia fluxes and derived canopy compensation points over non-fertilised agricultural grassland in The Netherlands using the new gradient ammonia - high accuracy - monitor (GRAHAM), Atmos. Environ., 41, 1275-1287, 2007.

Wu, Y., Walker, J., Schwede, D., Peters-Lidard, C., Dennis, R., and Robarge, W.: A new model of bi-directional ammonia exchange between the atmosphere and biosphere: Ammonia stomatal compensation point, Agr. Forest Meteorol., 149, 263-280, 2009.

Zhang, L., Brook, J. R., and Vet, R.: A revised parameterization for gaseous dry deposition in air-quality models, Atmos. Chem. Phys., 3, 2067-2082, 2003,

http://www.atmos-chem-phys.net/3/2067/2003/. 